\section{OPEN ACCESS}

Edited by:

Jean Armengaud,

Commissariat à l'Energie Atomique et aux Energies Alternatives (CEA),

France

Reviewed by:

Camila Fernandez,

UMR7621 Laboratoire

d'Océanographie Microbienne

(LOMIC), France

Karima Hezbri,

National Institute of Applied Science

and Technology, Tunisia

${ }^{*}$ Correspondence:

Michael Seeger

michael.seeger@usm.cl

Specialty section:

This article was submitted to

Microbiotechnology, Ecotoxicology

and Bioremediation,

a section of the journal

Frontiers in Microbiology

Received: 30 April 2018

Accepted: 10 September 2018

Published: 30 October 2018

Citation:

Orellana R, Macaya C, Bravo G, Dorochesi F, Cumsille A, Valencia R, Rojas C and Seeger M (2018) Living at the Frontiers of Life: Extremophiles

in Chile and Their Potential

for Bioremediation.

Front. Microbiol. 9:2309.

doi: 10.3389/fmicb.2018.02309

\title{
Living at the Frontiers of Life: Extremophiles in Chile and Their Potential for Bioremediation
}

\section{Roberto Orellana ${ }^{1,2}$, Constanza Macaya1, Guillermo Bravo', Flavia Dorochesi', Andrés Cumsille ${ }^{1}$, Ricardo Valencia ${ }^{1}$, Claudia Rojas ${ }^{1}$ and Michael Seeger ${ }^{1 *}$}

\begin{abstract}
'Laboratorio de Microbiología Molecular y Biotecnología Ambiental, Departamento de Química and Centro de Biotecnología Daniel Alkalay Lowitt, Universidad Técnica Federico Santa María, Valparaíso, Chile, ${ }^{2}$ Departamento de Biología, Facultad de Ciencias Naturales y Exactas, Universidad de Playa Ancha, Valparaíso, Chile
\end{abstract}

Extremophiles are organisms capable of adjust, survive or thrive in hostile habitats that were previously thought to be adverse or lethal for life. Chile gathers a wide range of extreme environments: salars, geothermal springs, and geysers located at Altiplano and Atacama Desert, salars and cold mountains in Central Chile, and ice fields, cold lakes and fjords, and geothermal sites in Patagonia and Antarctica. The aims of this review are to describe extremophiles that inhabit main extreme biotopes in Chile, and their molecular and physiological capabilities that may be advantageous for bioremediation processes. After briefly describing the main ecological niches of extremophiles along Chilean territory, this review is focused on the microbial diversity and composition of these biotopes microbiomes. Extremophiles have been isolated in diverse zones in Chile that possess extreme conditions such as Altiplano, Atacama Desert, Central Chile, Patagonia, and Antarctica. Interesting extremophiles from Chile with potential biotechnological applications include thermophiles (e.g., Methanofollis tationis from Tatio Geyser), acidophiles (e.g., Acidithiobacillus ferrooxidans, Leptospirillum ferriphilum from Atacama Desert and Central Chile copper ores), halophiles (e.g., Shewanella sp. Asc-3 from Altiplano, Streptomyces sp. HKF-8 from Patagonia), alkaliphiles (Exiguobacterium sp. SH31 from Altiplano), xerotolerant bacteria (S. atacamensis from Atacama Desert), UV- and Gamma-resistant bacteria (Deinococcus peraridilitoris from Atacama Desert) and psychrophiles (e.g., Pseudomonas putida ATH-43 from Antarctica). The molecular and physiological properties of diverse extremophiles from Chile and their application in bioremediation or waste treatments are further discussed. Interestingly, the remarkable adaptative capabilities of extremophiles convert them into an attractive source of catalysts for bioremediation and industrial processes.

Keywords: extremophile, Chile, Atacama Desert, Altiplano, Patagonia, Antarctica, bioremediation

\section{INTRODUCTION}

Most the well-described forms of life are mainly adapted to face environments with "physiological conditions," a term described in literature as moderate temperature $\left(10-37^{\circ} \mathrm{C}\right)$, $\mathrm{pH} \sim 7$, salinity ranging from 0.15 to $0.5 \mathrm{M} \mathrm{NaCl}$, pressure 1 atm and enough water availability (Aguilar et al., 1998; Antranikian et al., 2005). However, there is still a large under-examined group of organisms, known as extremophiles, that are capable of adjust, 
survive or thrive in hostile habitats that were previously thought to be inhospitable or even lethal for life (Rampelotto, 2013). In general, extremophiles are divided in two categories: extremophiles, which require one or more extreme conditions to grow, and extremotolerant organisms, which can tolerate extreme and/or toxic conditions, although they grow optimally at "physiological" conditions (Canganella and Wiegel, 2011). The study of extremophiles is a rather difficult field, mainly constrained by the complexity of reaching their ecological niches and isolating these microbes. Most extremophiles are still part of the microbial dark matter that has not been discovered yet (Bernard et al., 2018). Hunting microbes in extreme environment is a huge challenge for microbiologists worldwide, which could provide microorganisms, enzymes and biomolecules for diverse applications in biotechnology, biomedicine and industrial processes. The knowledge of the adaptation mechanisms of microbes to extreme environments provides metabolic networks, regulation circuits and pieces for systems biology and synthetic biology (Chen and Jiang, 2018). Extreme conditions drive the evolution of their inhabitants, highlighting the role of extremophiles as models for the study of the evolution of biological entities.

Newly developed technologies have allowed research on extreme environments to gain knowledge on microorganisms and provide significant insights about the origin of life on Earth. Recent studies have uncovered that the first terrestrial life form, known as LUCA (Last Universal Common Ancestor), was a thermophilic anaerobe capable of gaining energy from geochemical sources (Weiss et al., 2016). Basic research has provided valuable insights on how extremophiles can survive such challenging environments. However, the presence of highly sophisticated mechanisms of adaptation together with the availability of a sweet of novel biochemical pathways sustaining peculiar physiological metabolic capabilities converts extremophiles into a current focus of applied research to exploit their biotechnological potential (Rampelotto, 2013). Further attention has also been devoted to identification, isolation and characterization of biomolecules, most of them enzymes named as extremozymes, which are well adapted to be active also at extreme conditions (Rampelotto, 2013).

Extremophiles, can be classified according to the conditions in which they grow: thermophiles and hyperthermophiles (organisms growing at temperatures of $45-80^{\circ} \mathrm{C}$ and $>80^{\circ} \mathrm{C}$, respectively) (Madigan et al., 2000; Berenguer, 2011), psychrophiles (organisms that grow at $<10^{\circ} \mathrm{C}$ ) (Siddiqui et al., 2013), acidophiles and alkaliphiles (organisms optimally adapted to $\mathrm{pH}<5$ and $\mathrm{pH}>9$, respectively), halophiles (organisms that require $\mathrm{NaCl}$ for growth, in concentration of 200-5,900 mM) (Edbeib et al., 2016), microorganisms that survive in dry environments (water activity $<0.75$ ) (Connon et al., 2007) and radiotolerant (UV resistant) extremophiles that are resistant to the permanent exposure to damaging solar radiation (Gabani et al., 2014) (Table 1). Additionally, it is worth mentioning that extremophiles are usually defined by one extreme condition, nevertheless, many natural environments possess two or more extreme conditions. The microbiota living on those ecosystems, also known as polyextremophiles, is adapted to an additional extreme condition to the one condition that characterizes them, such as temperature, $\mathrm{pH}$, salinity (Urbieta et al., 2015b).

Chile occupies a long strip of territory in the south west of South America and with other countries shared part of the Antarctica. It has been referred to be a "biogeographic island" (Scherson et al., 2017), due to a series of geological events that have formed the current natural barriers Altiplano, Atacama Desert, Los Andes Mountains, Pacific Ocean, Patagonia, and Antarctica (Villagrán and Hinojosa, 1997; Villagrán and Armesto, 2005). Due to its extremely diverse geography and singular geochemical and climatic conditions, Chile gathers many extreme environments, which may result intolerably hostile or even lethal for most life forms, except for extremophiles (Rampelotto, 2013). In order to enable growth under these harsh conditions, extremophiles have been subjected to several adaptations, which have been only partially characterized to date. Altiplano, Atacama Desert, Central Chile, Patagonia, and Antarctica correspond to main geographical areas in Chile that harbor multiple extreme biotopes (Figure 1). Specific extreme biotopes of Chile are attractive scenarios to study the evolution of microorganisms under extreme conditions, which resemble the islands of the Galapagos Archipelago that provide Darwin inspiring ideas to build up the Theory of Evolution by Natural Selection of macroorganisms based on the divergence of species of birds, especially the Galapagos finches.

The preservation of the natural ecosystems and the restauration of polluted sites are crucial for a sustainable

TABLE 1 | General description of extremophiles present in diverse extreme environments of Chile.

\begin{tabular}{|c|c|c|c|c|}
\hline Environmental parameter & Extremophile & Definition & Example & Reference \\
\hline \multirow[t]{3}{*}{ Temperature } & Hyperthermophile & Growth $>80^{\circ} \mathrm{C}$ & Pyrococcus sp. M24D13 & Dennett and Blamey, 2016 \\
\hline & Thermophile & Growth $45-80^{\circ} \mathrm{C}$ & Methanofollis tationis & Zabel et al., 1984 \\
\hline & Psychrophile & $\leq 10^{\circ}$ & Pseudomonas sp. ATH-43 & Rodriguez-Rojas et al., 2016a \\
\hline \multirow[t]{2}{*}{$\mathrm{pH}$} & Acidophile & $\mathrm{pH}<5$ & Acidithiobacillus ferrooxidans & Demergasso et al., 2010 \\
\hline & Alkaliphile & $\mathrm{pH} \geq 9$ & Halomonas alkaliphila & Quiroz et al., 2015 \\
\hline Salinity & Halophile & $2,000-5,000 \mathrm{mM} \mathrm{NaCl}$ & Haloferax sp. CL47 & Bonfá et al., 2011 \\
\hline UV radiation & Radioresistant & Radiation tolerant (40-400 nm) & Deinococcus peraridilitoris & Rainey et al., 2007 \\
\hline Water availability & Dehydration tolerant & Growth water activity $<0.75$ & Streptomyces bulli & Santhanam et al., 2013 \\
\hline
\end{tabular}




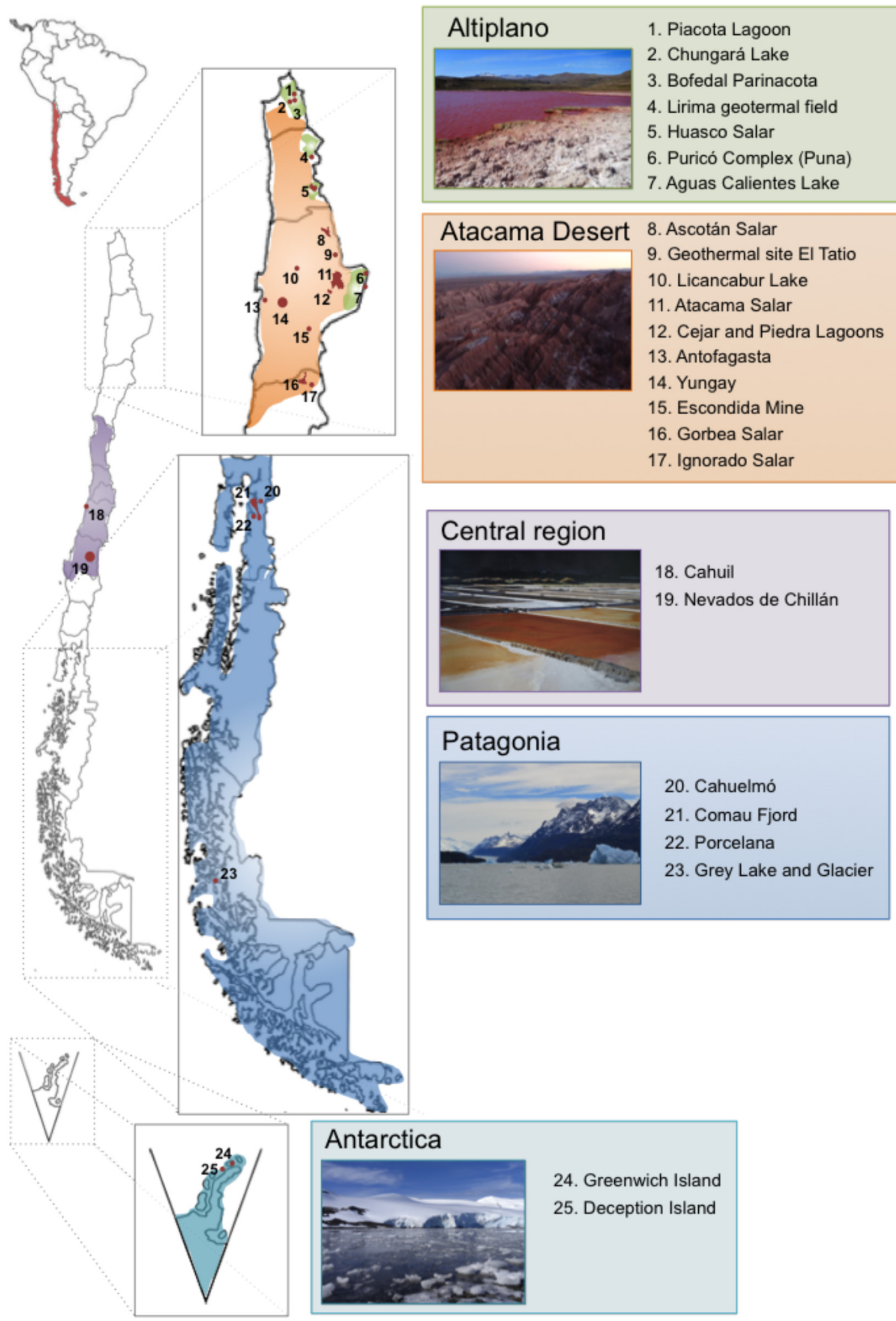

FIGURE 1 | Distribution of different extreme ecosystems harboring extremophiles in five main biotopes throughout Chile. Altiplano (photography: Red Lagoon, Amuyo, Camarones, Parinacota Region), Atacama Desert (photography: Moon Valley, San Pedro de Atacama, Antofagasta Region), Central Region (photography: Cahuil Saltern, Nilahue, O'Higgins Region), Patagonia (photography: Grey Lake and Glacier, Magallanes Region), and Antarctica (photography: Arturo Prat Station, Greenwich Island). 
development. Bioremediation is an important technology for the clean up of environments contaminated with persistent organic pollutants [e.g., pesticides, polychlorobiphenyls (PCBs), petroleum hydrocarbons] and heavy metals (e.g., $\mathrm{Hg}, \mathrm{Cd}$ ) (Morgante et al., 2010; Saavedra et al., 2010; Rojas et al., 2011; Fuentes et al., 2014; Bravo, 2017). Mining of valuable metals such as copper, gold and silver is historically one the most relevant economic activities in Chile, mainly in the Northern and Central regions. Copper mining is the main activity in Chile, contributing with one third of the world's production. Unfortunately, this mining activity has been associated with heavy metal pollution in diverse sites. Microorganisms are main biocatalysts for bioremediation of polluted environments and waste treatment processes (Hernández et al., 2008a,b; Saavedra et al., 2010; Rojas et al., 2011; Fuentes et al., 2016; Méndez et al., 2017) and extremophilic microbes are required as catalysts for the bioremediation of polluted extreme environments. The aims of this review are to describe extremophiles that inhabit the main extreme biotopes in Chile, and their molecular and physiological capabilities that may be advantageous for the design and development of bioremediation processes.

\section{BIOTOPES AND ECOLOGICAL NICHES}

Chilean territory is spanned within a long altitudinal and latitude range that contributes to the origin of a suite of landscapes and geological features that are extreme habitats for microorganisms. Some of these ecosystems will be described briefly.

\section{Atacama Desert}

The Atacama Desert is located along the western border of South America and is the driest and oldest desert on Earth's, exhibiting similar conditions described for Mars. This ecosystem provides a unique collection of habitats, ideal for studying microbial dynamics in several extreme conditions, such as alkaline or acidic $\mathrm{pH}$, high temperature, water stress, and UV radiation (Figure 1). Its distinctive climate is the result of the confluence of a subtropical high-pressure zone, the cold Humboldt Current on the coast, offshore winds, as well as the Andean rain-shadow effect and latitudinal position of the region (Houston and Hartley, 2003).

\section{Altiplanic Ecosystems}

The Andean Altiplano occupies part of Peruvian, Bolivian, and Chilean territory with a mean altitude of $3,700 \mathrm{~m}$ above sea level and covers an area that is $300 \mathrm{~km}$ wide and 1,500 km long (Muñoz and Charrier, 1996). The Altiplano is surrounded by volcanoes and mountains rising up to 6,700 $\mathrm{m}$ and represents one of the largest plateaus in the world. The Altiplano possess several extremes environments, such as thermal waters and geysers, some basins, salars, large lakes in the north and salt flats in the south. Some of the more characteristic Altiplano ecosystems are described below.

\section{Parinacota Region}

The paleolakes Chungará Lake, Parinacota Wetland, and Piacota Lagoon are located 4,300-4,500 $\mathrm{m}$ above sea level. The microbial community composition is highly variable between the different wetlands, but also between water and sediment samples (Dorador, 2007). Each of these environments supported a unique community of Bacteria and Archaea, revealing a differentiation between high altitude lakes, freshwater wetlands, and saline wetlands.

\section{Geothermal Springs and Geysers}

The extreme conditions (high temperature and pressure) are characteristic of hot springs and geysers located in the Northern region and is the result of the permanent interaction of groundwater with magma and hot igneous materials stemming from near the rather abundant volcanic areas (Jones and Renaut, 1997; Fernandez-Turiel et al., 2005; Rafferty, 2010).

The Geothermal site El Tatio (Kunza language, meaning "crying grandfather") is the largest geyser field in the Southern hemisphere and one of highest geysers around the world $(\sim 4,200$ m.a.s.l.) (Glennon and Pfaff, 2003). Located on the Andean Altiplano, it harbors over 100 erupting springs and is surrounded by high volcanoes. The water discharged by the Tatio Geyser is very rich in silica, with the highest concentrations reported for a natural surface water, of both arsenic $(\sim 0.5 \mathrm{mM})$ and antimony $(\sim 0.02 \mathrm{mM})$ at a nearly neutral pH (Landrum et al., 2009). These properties differ from other well-studies geothermal sites, such as basins in Yellowstone National Park, United States, and Dallol Volcano, Ethiopia, for which their waters can reach extreme pH values (Rowe et al., 1973; Barbieri and Cavalazzi, 2014). Therefore, El Tatio in an environment with unique physicochemical characteristics.

The North regions of Chile harbor many hydrothermal fields that remained less explored than El Tatio. For instance, the Surire hydrothermal system, at 4,000 m.a.s.l., is located in the south part of Surire Salar (Procesi, 2014). The water discharges are characterized by higher concentration of sulfate. Analogous situation occurs with Lirima Geothermal field that is located at an altitude of 3,900 m.a.s.l., $25 \mathrm{~km}$ southwest of the Sillajhuay volcanic chain. The Lirima area contains bubbling pools with temperatures between $38^{\circ} \mathrm{C}$ and $80^{\circ} \mathrm{C}$ (Tassi et al., 2010; Procesi, 2014).

\section{Salars}

Chile harbors a huge diversity of salars along its territory. Saline ecosystems are located in Altiplano, Atacama Desert, Central Chile, and Patagonia. Specific salars that has been subjected to microbial studies will be described.

\section{Athalassohaline Ecosystem: Huasco Salar}

Athalassohaline systems are saline ecosystems with a non-marine origin but originated from evaporation of fresh water in a system dominated by calcium, magnesium and sulfate, in contrast with sodium and chloride that are prevalent in the ocean (Grant, 2006). At 3,800 $\mathrm{m}$ above sea level, Huasco Salar is a good example of an athalassohaline system (Dorador et al., 2010). These systems exhibit extreme conditions such as low temperatures 
and atmospheric pressure, high solar radiation, negative water balance, and a wide range of salt concentrations (Castro-Severyn et al., 2017).

\section{Acidic Salars: Ignorado Salar and Gorbea Salar}

Two acidic salars in Chile are located in the Andes Mountains (Risacher et al., 2003). Gorbea Salar is located in a basin with extreme acidic brines, with $\mathrm{pH}$ ranging from 2 to 4 and $\mathrm{NaCl}$ concentrations from 0.03 to $1.3 \mathrm{M}$ (Quatrini et al., 2017). Ignorado Salar is an acid saline lake, with surface waters with $\mathrm{pH}$ ranging from 3.3 to 4.1 and a total dissolved solids concentration from 0.5 to $3 \%$ (Karmanocky and Benison, 2016).

\section{Borderline Salar: Atacama Salar}

Salar de Atacama is located between the Atacama Desert and the westernmost margin of the Altiplano at 2,300 $\mathrm{m}$ above sea level (Zúñiga et al., 1991). It is the largest and oldest evaporating basin in Chile, and the largest Quaternary halite deposit worldwide (Warren, 2010; Lara et al., 2012). Salar de Atacama has some shallow lakes with high salt concentration (Zúñiga et al., 1991) and with distinct geological features compared to the Altiplano basins (Demergasso et al., 2010).

\section{Central and Southern Salars}

Other saline ecosystems are also located in the Central Region and the Southern Patagonia (De Los Rios-Escalante and Gajardo, 2010; Plominsky et al., 2014). Cáhuil Lagoon is a saline ecosystem located at the coast close to Pichilemu in Central Chile (Figure 1).

\section{Patagonia}

Patagonia is comprised by an extensive structure of cold fjords (e.g., Comau Fjord) and channels, and by oligotrophic cold lakes in Southern Chile, characterized by low temperatures, low nutrient concentration and low dissolved organic carbon (Gutiérrez et al., 2015; Aguayo et al., 2017). Cold lakes in Patagonia (e.g., Grey Lake, Figure 1) are affected by seasonal temperature variations, ranging from $4^{\circ} \mathrm{C}$ in winter to $20^{\circ} \mathrm{C}$ in summer (Aguayo et al., 2017).

Volcanic activity has been also reported with a high eruption frequency (Carrillo et al., 2018), which has formed numerous hydrothermal fields including Porcelana Hot Spring and Geyser, and Cahuelmo Hot Spring. Cahuelmo Hot Spring is a geothermal site located at the sea level coast of Cahuelmo Fjord, that contains waters rich in metallic minerals and elements such as pyrite, polonium, magnetite, and chalcopyrite (Mackenzie et al., 2013). On the other hand, Porcelana hot spring is located $\sim 100 \mathrm{~m}$ above sea level in Northern Patagonia. Porcelana is a pristine spring characterized by a rather extensive thermal gradient $\left(\sim 38-69^{\circ} \mathrm{C}\right)$ and neutral pH (Alcamán et al., 2015).

\section{Antarctica}

Antarctica displays extreme climates and environmental conditions above and below the water surface. This environment is dominated by strong gradients in temperature $\left(-10^{\circ} \mathrm{C}\right.$ to $\left.-2^{\circ} \mathrm{C}\right)$, salinity $(35-150 \%)$, and irradiation $(<0.1 \%$ to $1-5 \% \mathrm{UV}$ radiation), properties highly variable and ultimately governed by air temperature and snow cover (Cirés et al., 2017). The search of new pigments, antibiotics, and enzymes has become a main research focus in the Antarctic continent (Loperena et al., 2012; Órdenes-Aenishanslins et al., 2016; Lavin et al., 2017). In spite of been the coldest continent on Earth, surprisingly, Antarctica harbors many geothermal sites.

\section{THERMOPHILES}

Early life in Earth was initially dominated by thermophilic anaerobes that had chemoheterotrophic or chemolithoautotrophic metabolism capable of been sustained by hydrothermal energy sources (Woese et al., 1990; Konhauser et al., 2003; Weiss et al., 2016). Thermophiles are organisms, mainly prokaryotes, whose optimum growth temperatures are $>44^{\circ} \mathrm{C}$ (Madigan et al., 2000). Hyperthermophiles are thermophiles that grow at temperatures $>80^{\circ} \mathrm{C}$ (Berenguer, 2011) (Table 1). Thermophiles and hyperthermophiles are present in several natural ecosystems such as geothermal waters (Figure 2), hot springs, mud pots, fumaroles, geysers, deep-sea hydrothermal vents, volcanoes, and also in engineered environments, such as compost facilities and anaerobic reactors (Ahring, 1995; Rastogi et al., 2010; Urbieta et al., 2015b).

A general mechanism of thermophiles to safeguard their cellular components at high temperature is the adaption of thermophilic proteins through amino acid changes in their primary structure, increasing their thermal stabilities (Xu et al., 2018). Thermophilic proteins possess a larger fraction of amino acid residues in $\alpha$-helices and have shorter amino acid length (Urbieta et al., 2015a; Xu et al., 2018). A main mechanism in thermophiles is the role of heat shock proteins (HSPs) including the chaperones DnaK, GroEL, and GroES to assist protein folding (Figure 3). DNA-repair systems (e.g., SOS system) are also active to respond to DNA damage. For the stabilization of the membranes, thermophiles use branched chain fatty acids and polyamines (e.g., spermidine). Another mechanism of thermophiles is the use of compatible solutes to stabilize cell components (Urbieta et al., 2015a). In addition, upregulated glycolysis pathway (e.g., pyruvate dehydrogenase complex) proteins provide immediate energy to cope with heat stress (Wang et al., 2015).

An increase in the use of (hyper)thermophilic microorganisms has been observed, especially for the need of the industry to couple biological solutions at high-temperature industrial processes (Urbieta et al., 2015a). Industrial waste reactors containing living microorganisms required to be pre-cooled down due to the fact that several industrial processes are carried out at temperatures $>100^{\circ} \mathrm{C}$ (Gavrilescu, 2010). Therefore, (hyper)thermophiles offer a suitable solution due to their capabilities to grow at such high-temperature and also resist and metabolize several pollutants from contaminated industrial wastewaters (Vieille and Zeikus, 1996). Previous studies have demonstrated the high potential of (hyper)thermophilic pure cultures and consortia for bioremediation of heavy 


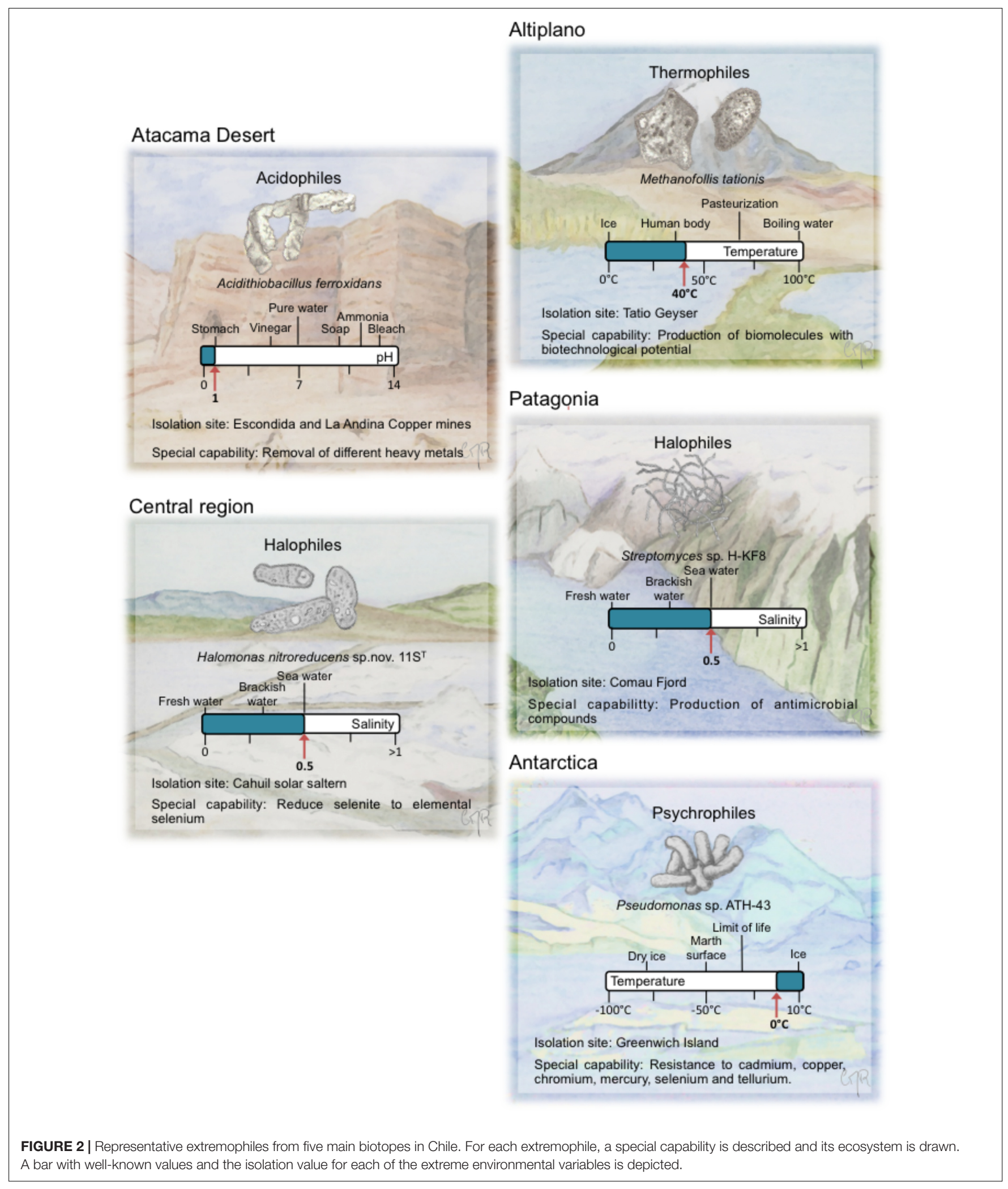

metal-contaminated surface and groundwaters, including biosorption and immobilization of radionuclides and heavy metals (Chatterjee et al., 2010; Sar et al., 2013), removal of heavy metals (Ilyas et al., 2014) and for degradation of persistent organic compounds such as aliphatic and (poly)aromatic hydrocarbons (Mnif et al., 2014; Zhou et al., 2018), and synthetic 


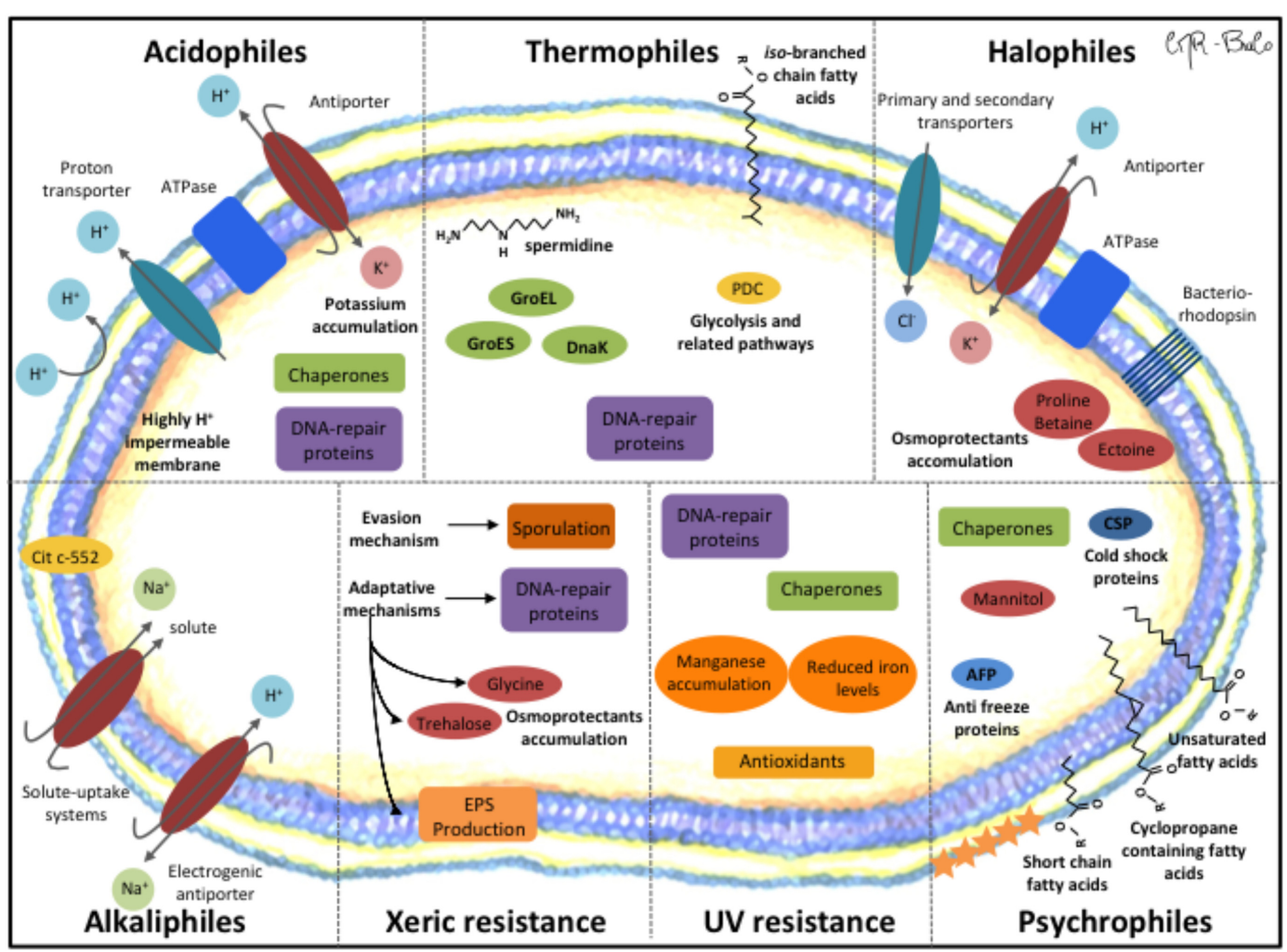

FIGURE 3 | Molecular mechanisms of extremophiles for their adaptation to extreme environmental conditions. Acidophiles. (i) Potassium antiporter releases protons towards the extracellular medium, (ii) ATP synthase, (iii) membrane highly impermeable to protons, (iv) Chaperones, and (v) DNA-repair proteins. Thermophiles. (i) Upregulated glycolysis proteins (e.g., pyruvate dehydrogenase complex (PDC)), (ii) Lipids with iso-branched chain fatty acids and long chain dicarboxylic fatty acids, (iii) polyamines (spermidine), and (iv) Chaperones. Halophiles. (I) High salt-in strategy: (i) chloride transporters (primary or secondary), (ii) potassium uptake into cells by concerted action of bacteriorhodopsin and ATP synthase. (II) Low-salt strategy: (i) de novo synthesis or uptake of osmoprotectants (proline-betaine, ectoine) that maintain osmotic balance and establish the proper turgor pressure under different salt concentration. Psychrophiles. (i) high degree of unsaturated, cyclopropane containing fatty acids and short chain fatty acids, (ii) Cold shock proteins (CSP) (iii) Chaperones, (iv) Anti-freeze proteins (AFP) restrict the ice growth on protein surfaces, (v) Mannitol and other compatible solutes accumulate in the cell cytoplasm as cryo-protectants to prevent protein aggregation, and (vi) Carotenoids (star symbols) support maintenance of membrane fluidity and prevent cell damage by UV radiation. UV resistance. (i) Manganese accumulation and reduced iron levels, (ii) Antioxidants (glutathione), (iii) Chaperones, and (iv) DNA-repair proteins. Xeric resistance. (I) Evasion mechanism: (i) bacteria sporulation. (II) Adaptation mechanism: (i) increased extracellular polymeric substances (EPS), (ii) DNA-repair proteins, and (iii) accumulation of osmoprotectants (glycine, trehalose). Alkaliphiles. (i) Electrochemical gradient of $\mathrm{Na}^{+}$and $\mathrm{H}^{+}$by electrogenic antiporters for proton accumulation, (ii) $\mathrm{Na}^{+}$-solute uptake system, and (iii) Cytochrome c-552 enhance terminal oxidation function by electron and $\mathrm{H}^{+}$accumulation.

dyes (Deive et al., 2010). Increasing research is conducted into evaluating the applications of thermostable enzymes in waste treatment and remediation (Kataoka et al., 2014; Wang et al., 2015; Rigoldi et al., 2018).

A high portion of the Chilean territory is superimposed on the subducting Nazca plate, the largest tectonic relief, that drives displacement and rearrangements of geological structures and generates routinely megathrust earthquakes (Armijo et al., 2015). In those areas, the compression and decompression of magma may modulate volcanic activity on land, in the seafloor, and in the deep subsurface, generating abundant natural formations that are suitable for survival and growth of (hyper)thermophilic microbial life forms. Geothermal fields are usually main contributors of arsenic to both surface and subsurface water (Ballantyne and Moore, 1988; Smedley and Kinniburgh, 2002). The water influx is particularly important at the water discharged at the Tatio Geyser, which achieved in surface water a arsenic concentration of $45 \mathrm{mg}$
$\mathrm{L}^{-1}$ (Landrum et al., 2009). The effluent discharges caused high arsenic levels (0.1-1.5 $\left.\mathrm{mgL}^{-1}\right)$ throughout the basin of Loa River. Besides the potential human health risks (Yañez et al., 2005), those arsenic levels impact also the microbiota. Pseudomonas fluorescens and Serratia odorifera strains isolated from an arsenicpolluted river in the Atacama Desert showed tolerance to arsenic 800-1,000 mM (Campos et al., 2009; Escalante et al., 2009). Due to their physicochemical properties, the water discharged by the Tatio Geyser is an unique environment to study (hyper)thermophiles. A fraction of the water is very rich in silica, contains high antimony concentration $(\sim 0.02 \mathrm{mM})$, low sulfite concentration $(\sim 0.5 \mathrm{mM})$ at a nearly neutral $\mathrm{pH}$ (Landrum et al., 2009). Most of the worldwide studies efforts directed to the biotransformation of arsenic by (hyper)thermophiles have been restricted to sulfidic waters at extreme $\mathrm{pH}$ conditions, including high arsenic geothermal sites in Yellowstone National Park in United States and Dallol Volcano in Ethiopia (Rowe et al., 1973; 
Barbieri and Cavalazzi, 2014). Research has been focused toward isolation and characterization of (hyper)thermophiles tolerant to As, or capable of playing a role on its biogeochemical cycle. The geothermal water discharges arsenite As(III), which is the most mobile and toxic form of arsenic that progressively oxidizes to arsenate As(V) downstream (Engel et al., 2013). Several prospections have shown that nearly all of the geyser features and streams at El Tatio are covered by biofilms and colorful microbial mats dominated by photosynthetic bacteria (Chloroflexi and cyanobacterial communities) (Fernandez-Turiel et al., 2005; Engel et al., 2013; Plenge et al., 2017). Microbial community analysis based on 16S rRNA gene of the geyser-discharge water revealed that Chloroflexi, Deinococcus-Thermus, Aquificales, and Chlorobi were the most prevalent microorganisms in the zones where arsenite reduction takes place (Engel et al., 2013). Indeed, the survey of functional genes revealed that most of the arsenite oxidase aioA-like gene found within the community showed high identity to genes belonging to strains of the thermophilic anoxygenic phototroph Chloroflexus aurantiacus. Chloroflexi-like aioA gene sequences obtained from the microbial community of El Tatio clustered on two separated clades likely representing additional diversity that could be associated with either novel groups of arsenic-resistant bacteria, or novel mechanisms of As resistance. It is also noteworthy to mention that Chloroflexus aurantiacus can either grow phototrophically under anaerobiosis or chemotrophically under aerobic and dark conditions, providing enough metabolic flexibility to function as a potential strain for bioremediation of As-contaminated environments, but also during carbon sequestration efforts (Tang et al., 2011).

Besides arsenic, the microbial communities associated to El Tatio cope with a wide variety of environmental stressors, such as the presence of other toxic metals (e.g., antimony) and the impact of extreme UV radiation. Living at such selective pressure has fostered the development and retention of a suite of metabolic and physiological adaptations that has enormous potential to be used for biotechnological applications. On one hand, multi-resistant microbial isolates may be useful in bioremediation. Furthermore, a second area of interest is the identification and characterization of the mechanisms of resistance to multiple stressors. Indeed, enzymes synthesized by (hyper)thermophiles display high levels of thermostability, converting them in candidates to explore potential novel applications for industrial processes. For example, the archaeon isolated from a solfataric pool located in El Tatio, Methanofollis tationis (Figure 2, first described as Methanogenium tatii) (Zabel et al., 1984; Zellner et al., 1999) produced its own particular pterin, a type of biomolecule involved in immune modulation, cellular signaling, metabolism and pigmentation. Two years after its isolation, the identification and structure of the novel pterin produced by Methanofollis tationis, named tatiopterin, were elucidated. Afterward, it has been shown that tatiopterin specifically enhances photostability of materials, preventing the bleaching of photosynthetic pigments due to irradiation (Elshahawi et al., 2015). More efforts in order to understand the role of such molecules under those conditions should be further explored. Specifically, one area of interest in this field is the increase of exploration efforts of novel thermozymes that can be applied for production of biofuels from starch and lignocellulosic waste materials. Due to their complex structure, lignocellulosic materials are degraded by physicochemical treatments to obtain cellulose, hemicellulose, and lignin, which can be further treated with hydrolytic enzymes (Urbieta et al., 2015a).

Previous prospections in the Surire Salar have described the presence of arsenic-precipitating bacteria, suggesting that may be also present in the Surire hydrothermal vents (Demergasso et al., 2007). The culturable mesophiles in Lirima wetland were reported, whereas the hot spring remain unexplored (Scott et al., 2015). Special attention should be devoted in this site due to the fact that water contain high chloride and boron concentrations, becoming a source of microorganisms capable of bioremediation of boron-polluted wastewaters. Microbes associated to the hydrothermal systems such as Puchuldiza-Tuja (4,100 m.a.s.1.), Colpitas (4,000 m.a.s.1.), Apacheta (4,500 m.a.s.l.) have not been explored yet.

Porcelana hot spring in Northern Patagonia is characterized by abundant and colorful microbial mats widespread along a rather extensive thermal gradient $\left(\sim 38-69^{\circ} \mathrm{C}\right.$ ) (Alcamán et al., 2015). The microbial community associated to Porcelana hot spring is dominated by cyanobacteria, particularly of the diazotrophic Mastigocladus (Stigonematales) genus. Members of the same genus were also identified as part of biofilms in Copahue geothermal field at the North west corner of Neuquén province, Argentina (Urbieta et al., 2015b), indicating its cosmopolitan character (Miller, 2007). At Porcelana hot spring, Mastigocladus sp. strain CHP1 was the most dominant contributor of nitrogen through nitrogen fixation ( $\sim 87 \%$ of the nifH gene transcripts) (Alcamán et al., 2015). Physiological studies revealed that Mastigocladus isolates gather a broad range of metabolic plasticity regarding the nitrogen metabolism (Alcamán et al., 2017). Mastigocladus sp. strain CHP1 is capable to fix nitrogen at $60^{\circ} \mathrm{C}$, the highest temperature reported for the activity of $\mathrm{N}_{2}$-fixing filamentous cyanobacteria (Alcamán et al., 2015). Further studies should explore the metabolic versatility of Mastigocladus sp. strain CHP1 in the treatment of nitrate-contaminated industrial waters at high temperature.

Environments are so dynamic that surprise us. An iconographic example of such diversity is depicted by the fact that Antarctica, a continent well known as the coldest place on earth, also harbors many geothermal sites suited for the growth of (hyper)thermophile microorganisms (Flores et al., 2013). The uppermost temperatures of those sites range from 40 to $110^{\circ} \mathrm{C}$, and has extremely low concentrations of nutrients, such as $\mathrm{N}$ and $\mathrm{P}$, and high concentrations of heavy metals $(\mathrm{Cu}, \mathrm{Zn}, \mathrm{Cd}, \mathrm{Pb}$, and Hg) (Muñoz et al., 2011). Although environmental conditions seem to be harsh for microbial growth, recent studies have shown that the environment is suitable for thermophilic organisms. Bacteria from the Geobacillus, Bacillus, Brevibacillus, Thermus genera and uncultured sulfate reducing bacteria were abundant in a fumarole at $90-110^{\circ} \mathrm{C}$ from Deception Island, an active strato volcano located in the South Shetland Islands (Muñoz et al., 2011). Some of these microbes can carry metal redox interactions that have further implications for ore formation and might be capable to recover metals from ore-containing 
materials. For instance, the thermophilic Geobacillus sp. strain ID17 is capable to synthesize gold nanoparticles when exposed to $\mathrm{Au}(\mathrm{III})$. The nanoparticles were found to be intracellularly accumulated raising the potential applications in bioremediation of gold-bearing wastes (Correa-Llantén et al., 2013). The synthesis of gold nanoparticles by bacteria can be useful for diverse biotechnological and medical applications (MonteroSilva et al., 2018). Geobacillus species are also capable to degrade organic pollutants. Indeed, members of the same clade including Geobacillus thermoleovorans T80 degrade hexadecane (70\%) during bioremediation at $\sim 60^{\circ} \mathrm{C}$. Archaea have also been isolated from soils extracted at Deception Island. Dennett and Blamey (2016) isolated the hyperthermophilic archaea Pyrococcus sp. M24D13, and characterized a novel thermostable cyanide-degrading nitrilase. This thermostable enzyme may be useful to remediate cyanide contaminated waste streams (Dennett and Blamey, 2016). (Hyper)thermophiles and their novel thermostable enzymes are of considerable biotechnological interest to find novel alternatives for bioremediation and other bioprocesses to be carried out at high temperatures.

\section{ACIDOPHILES}

Acidophiles are defined as organisms that grow at an optimum $\mathrm{pH}<5$ (Johnson, 2008). Extreme acidophiles are microorganisms that showed an optimum growth at $\mathrm{pH} 3$ or less, whereas moderate acidophiles are those that grow with optimum $\mathrm{pH}$ between 3 and 5 . Acid-tolerant microorganisms, have optimum $\mathrm{pH}>5$, but are still active in low $\mathrm{pH}$ environments (Johnson, 2007, 2008). Extreme acidophilic organisms are exclusively microbial and distributed in Archaea, Bacteria, and Eukarya domains (Sharma et al., 2016).

Acidophiles maintain the cytoplasmic $\mathrm{pH}$ close to neutrality to safeguard the acid-labile cellular constituents, which require the generation of a large $\mathrm{pH}$ gradient. Three main mechanisms are involved in the adaptation to an acidic environment (Figure 3). A first mechanism is an active pumping of protons to the maintenance of $\Delta \mathrm{pH}$, by proton flux systems. The role of proton efflux via transport pumps in the electron transport chain alongside the influx of protons through the $\mathrm{F}_{0} \mathrm{~F}_{1}$-type ATP synthase has been described in Bacillus acidocaldarius, Thermoplasma acidophilum, and Leptospirillum ferriphilum (Michels and Bakker, 1985). Additional proton flux systems include primary proton pumps (symporter) and secondary proton pumps (e.g., cation $/ \mathrm{H}^{+}$antiporter), and proton-consuming reactions. A carbonic anhydrase and amino acid decarboxylases that aid in $\mathrm{pH}$ homeostasis by consuming protons have been reported in L. ferriphilum (Christel et al., 2018). A second mechanism is a decreased permeability of the cell membrane to suppress the entry of protons into the cytoplasm. The influx of protons is inhibited by the inside positive membrane potential formed by $\mathrm{K}^{+}$ions (Christel et al., 2018). A wide repertoire of genes related to cell membrane biosynthesis that may be associated with acid tolerance was identified in L. ferriphilum. The presence of tetrapetric lipids in the cell membrane that provide tolerance to acidic $\mathrm{pH}$ has been reported in Archaea Ferroplasma acidiphilum and Sulfolobus solfataricus. A third mechanism is an improved protein and DNA-repair systems in acidophiles compared to neutrophils. An external pH shift from 3.5 to 1.5 induced proteins that are involved in the heat shock response such as chaperones in the acidophile At. ferrooxidans (Amaro et al., 1991).

Acidophilic microorganisms play an important role in biomining of metals from low grade sulfur minerals (Bustos et al., 1993; Seeger and Jerez, 1993; Seeger et al., 1996; Okibe et al., 2003; Demergasso et al., 2005, 2010; Acosta et al., 2017). Previous studies have demonstrated the role of acidophiles in bioremediation of polluted soils and waters, through (i) metal reductive processes (Kolmert and Johnson, 2001; Suzuki et al., 2003; Leigh et al., 2015), (ii) metal adsorption onto jarosites (Natarajan, 2008; Asta et al., 2009), (iii) metal biosorption (Liu et al., 2004; Chakravarty and Banerjee, 2012), and (iv) degradation of petroleum hydrocarbons (Stapleton et al., 1998; Margesin and Schinner, 2001; Christen et al., 2012; Arulazhagan et al., 2017). Additionally, enzymes from acidophilic microorganisms are explored due to their tolerance to low $\mathrm{pH}$, which favors their industrial applications in starch, fruit juices, feed and baking industries (Matzke et al., 1997; Nakayama et al., 2000; Serour and Antranikian, 2002; Sharma et al., 2012). More recently novel applications of acidophiles including electric generation have been explored (Sulonen et al., 2015; Ni et al., 2016).

Acidophilic microorganisms are present in several natural habitats, such as solfataric fields and geothermal sulfur rich sites (Sharma et al., 2016). These sites are niches for a variety of acidophilic microorganisms with unique adaptations for survival in the hostile low $\mathrm{pH}$ environments such as Sulfolobus solfataricus and Sulfolobus acidocaldarius (Yellowstone National Park, United States) (Brock et al., 1972). Acidophilic microorganisms have also been reported in anthropogenic environments such as acidic mine drainage (AMD), which are associated with heavy metals and coal mining. The acidophilic microorganisms mobilize metals and generate AMD. AMD generates most of the extremely acidic niches on Earth and disseminates heavy metals in the environment (Panda et al., 2016).

In Chile, an important area where acidophiles have been studied is located in the Atacama Desert. The microbial solubilization of metals in acidic environments has been successfully used in bioleaching for the extraction of metals. In Escondida mine located $170 \mathrm{~km}$ south-east from Antofagasta, the analyses of the microbial community of a low-grade copper sulfide leach pile indicated the presence of At. ferrooxidans (Figure 2), At. thiooxidans, L. ferriphilum, and F. acidiphilum (Galleguillos et al., 2008; Remonsellez et al., 2009; Demergasso et al., 2010; Acosta et al., 2017). Prokaryotic acidophile microarray (PAM) analysis showed members of Sulfobacillus genus in samples from heap leaching (Remonsellez et al., 2009). 16S rRNA genes phylogenetic analysis, real time PCR and metagenomics analysis revealed in the heap leaching the bacteria At. ferrooxidans, At. thiooxidans, At. caldus, At. ferrivorans, L. ferriphilum, S. acidophilus, S. thermosulfidooxidans, and Acidiphilium spp., and the archaea Ferroplasma acidiphilum, Ferroplasma acidarmanus, and Sulfolobus spp. 
(Demergasso et al., 2005, 2010; Soto et al., 2013; Acosta et al., 2017). Acidithiobacillus, Leptospirillum, and Sulfobacillus strains have also been reported in the copper tailings of $\mathrm{La}$ Andina mine in Central Chile (Figure 2). Molecular methods revealed the presence of heterotrophic acidophiles associated to Acidobacterium capsulatum, Acidobacterium-like bacterium and Acidiphilum sp. (Diaby et al., 2007). In Chile, solfataras throughout Andes Mountains (e.g., Purico Complex and Nevados de Chillán) that harbor acidophiles have been described. The moderate acidophile archaea $S$. solfataricus was isolated from a hot spring in Nevados de Chillán (Valdebenito-Rolack et al., 2017). To date, acidophilic microbes have been scarcely studied in diverse acidic environments in Chile including solfataras.

In the last decades, the bioremediation potential of acidophiles in acidic environments have been studied. Acidophiles capable to degrade phenol at low $\mathrm{pH}$ have been reported. The acidophile S. solfataricus degrades phenol (Christen et al., 2011). Zhou et al. (2016) reported the degradation by S. acidophilus of phenol, and methylphenols. Acidophilic bacteria able to grow in presence of alkanes have been described (Hamamura et al., 2005). Acidophiles including Acidisphaera, Acidiphilium, and Acidithiobacillus strains were capable to degrade 50\% hexadecane in hydrocarbon-amended soil/sand mixtures. Acidophiles have been used for the treatment of petroleum-polluted wastewater under acidic condition (Arulazhagan et al., 2017). Acidophilic microorganisms such as Acidithiobacillus and Sulfobacillus strains may be useful for the remediation of hydrocarbonpolluted acidic sites (Ivanova et al., 2013).

The removal of heavy metals by acidophiles from Chile has been reported. At. ferrooxidans has been used for removal of different heavy metals at laboratory scale. The addition of At. ferrooxidans to an AMD increased precipitation kinetics of heavy metals and decreased water iron content, accelerating heavy metal removal (Darkwah et al., 2005). At. ferrooxidans has been used for the ex situ bioremediation of uranium (VI), removing up to $50 \%$ of uranium $\left(100 \mathrm{mg} \mathrm{L}^{-1}\right)$ from polluted mine water (Romero-González et al., 2016). Takeuchi and Sugio (2006) reported that mercury was almost completely removed by volatilization in mercury-polluted soil by At. ferrooxidans strains SUG 2- 2 and MON-1. Also MON-1 cells immobilized in PVA resins efficiently volatilize mercury from mercurypolluted wastewater. Bioremediation by bioaugmentation with heavy metal-resistant bacteria of mercury-polluted waters has been reported (Rojas et al., 2011). This bioremediation process was scaled up (Bravo, 2017) and may be applied in mercury-polluted sites closed to metal mining activities. At. ferrooxidans and Leptospirillum ferrooxidans have been used for arsenite removal. Bioremoval occurs through the adsorption of arsenic (III) onto the jarosites generated during microbial growth (Natarajan, 2008). Furthermore, At. ferrooxidans and At. thiooxidans strains are able to reduce chromium (VI). The almost complete removal (93\%) of chromium (VI) from electroplating waste by $A$. thiooxidans has been reported (Cabrera et al., 2007). At. thiooxidans is able to reduce uranium by polythionates that are synthesized during oxidative sulfur metabolism (Gargarello et al., 2010). At. ferrooxidans has been applied for removing sulfur from solids and gases and heavy metals from electric wastes and sludge (Zhang et al., 2018). In addition, the removal of $\mathrm{Ni}$ and $\mathrm{Hg}$ from port sediments through bioaugmentation with a consortium of ironoxidizing acidophilic bacteria (A. thiooxidans, A. ferrooxidans, and $L$. ferrooxidans) in microcosm was observed (Beolchini et al., 2009).

Metal mining is a key player in the Chilean economy. Therefore, diverse acidophiles useful for bioleaching have been isolated, characterized and applied for bioleaching in Chile. Interestingly, some of these acidophilic microorganisms have been used at laboratory scale for the bioremediation of heavy metals and organic pollutants. However, the application of these acidophiles in bioremediation at industrial scale is still an important challenge. Acidophilic microbes from extreme environments are attractive biocatalysts for bioremediation processes under acidic conditions, especially for heavy metals.

\section{HALOPHILIC MICROORGANISMS}

Microorganisms belonging to the three domains of life are present over the whole range of salt concentrations in the environment (Oren, 1999). Halophiles are microorganisms that obligately require salt to grow (Margesin and Schinner, 2001). They are classified based on their optimal $\mathrm{NaCl}$ concentration for growth as slight halophiles $(0.2 \mathrm{M})$, moderate halophiles (0.5-2.5 M), borderline extreme halophiles $(>2.5-4.0 \mathrm{M})$ or extreme halophiles (>4.0-5.9 M) (Edbeib et al., 2016). Halophilic microorganisms are ubiquitous in salars, saline lakes, oceans, polar ice, and coastal areas (Edbeib et al., 2016). Halotolerants are microorganisms that grow in the presence and absence of $\mathrm{NaCl}$, and those that grow in presence of $>2.5 \mathrm{M} \mathrm{NaCl}$ are considered extremely halotolerant (Margesin and Schinner, 2001).

Halophilic and halotolerant microorganisms have adapted and evolved to survive in saline environments. They gather unique metabolic properties toward maintaining more water in the cytoplasm than in their surroundings, avoiding water losses. Halophilic or halotolerant microorganisms have evolved two main strategies (Figure 3). The first strategy is maintaining an intracellular salt concentration equivalent to the environment, and consequently, all intracellular systems have been adapted. This is achieved with chloride and potassium uptake into the cells by transporters (primary or secondary) and concerted action of bacteriorhodopsin and ATP synthase. The other strategy is maintaining low intracellular salt concentration, and therefore osmotic pressure is balanced by organic compatible solutes, such as betaine and ectoine. Due to its nature, the latter strategy does not require a global adaptation of the intracellular machinery (Oren, 1999; Margesin and Schinner, 2001).

Chile gathers several high saline environments. Most of them are concentrated in the Northern region, where 52 saline lakes and salt crusts are distributed alongside The Andes, spanning an area of over $200,000 \mathrm{~km}^{2}$ of the Atacama Desert. The saline ecosystems found in the Northern region can be classified in (i) Borderline Salars, (ii) Athalassohaline ecosystems, which are located in the Altiplano, and (iii) Acidic Salars (Risacher et al., 2003; Risacher and Fritz, 2009). Particularly, in Lejía 
Lake, an extreme saline lake nested at the base of Lascar Volcano in the Chilean Altiplano, two halotolerant bacteria closely related to Halomonas alkaliantarctica strain CRSS and capable to grow at $15 \% \mathrm{NaCl}$ were isolated (Mandakovic et al., 2018). Other saline lakes are also located in Central region (Cáhuil Lagoon), and the Southern Patagonia (De Los Rios-Escalante and Gajardo, 2010; Plominsky et al., 2014). One third of bacterial isolates from different niches in the Atacama Salar were classified as moderate halophilic and halotolerant bacteria. These isolates belong to Marinomonas, Vibrio, Alteromonas, Marinococcus, Acinetobacter, Micrococcus, Bacillus, Pseudomonas, Deleya, Staphylococcus genera and also some Cyanobacteria, such as members of the Cyanothece, Gloeocapsa, and Gloeobacter genera (Zúñiga et al., 1991; Dorador, 2007). Saltern ecosystems are commonly dominated by Archaea, where members of the family Halobacteriaceae are the most common halophiles (Oren, 2002). Metagenomic studies performed on samples extracted from a salt crystallizer pond located in the Cáhuil Lagoon, revealed that $61 \%$ of the gene sequences belonged to Archaea, mainly from the Halobacteriaceae family, followed by $19 \%$ sequences from viruses and 16\% from bacteria (Plominsky et al., 2014). Microbial communities in the Atacama Desert ecosystems, such as halites, saline soils and salt lakes, are also dominated by members of the Halobacteriaceae family (Robinson et al., 2015; Finstad et al., 2017).

Arsenic is a metalloid that is widely distributed at high concentrations along the Atacama Desert. The sources of arsenic are often associated with volcanic-hydrothermal springs, metal ores and anthropogenic activities. Microbial communities from Atacama Salar contributed to arsenic reduction (Lara et al., 2012), which is a process that has been widely studied in salinealkaline systems (Oremland et al., 2004; Kulp et al., 2007). Shewanella sp. strains Asc-3 and CC-1 isolated from Ascotán low-pH salt flats (Demergasso et al., 2007; Lara et al., 2012) were capable of precipitating arsenic (Table 2). Surprisingly, arsenic-precipitating bacteria accounted for $50 \%$ of the bacterial communities, suggesting that arsenic-based processes in this ecosystem are significant in the formation of arsenic minerals (Demergasso et al., 2007).

Exiguobacterium sp. SH31 isolated from a moderate saline environment in Huasco Salar was able of grow in presence of As(III) $10 \mathrm{mM}$ and As(V) $100 \mathrm{mM}$, highlighting its natural resistance to arsenic. Exiguobacterium strains capable of reducing arsenate and chromium have been reported. Interestingly, Exiguobacterium strains have been explored for bioremediation applications. An E. aurantiacum strain isolated from a lake in Southern Spain degrades pesticides (López et al., 2005). Microbacterium sp. CGR1 (Table 2) from the Atacama Desert tolerates $\mathrm{NaCl} 1.2 \mathrm{M}$, and possesses arsenic resistance (Mandakovic et al., 2015). An additional survey of metal resistance in halotolerant and halophilic isolates from the Atacama Desert showed that most of them were capable to cope with the presence of heavy metals such as $\mathrm{Cd}, \mathrm{Zn}, \mathrm{Ni}, \mathrm{Cu}$, and $\mathrm{Co}$. For example, Thalassobacillus devorans showed high tolerance to cadmium and nickel (Moreno et al., 2012).

Other Chilean ecosystems such as Cahuil marine salterns are sources for strains capable to be used in bioremediation platforms. The extreme halophile Haloferax sp. CL47 that was isolated in Cahuil degrades several polyaromatic hydrocarbons (PAHs) such as naphthalene, anthracene, phenanthrene, pyrene and benzanthracene (Bonfá et al., 2011). In addition, Haloferax sp. CL47 has been used for petroleum degradation in wastewater. The extreme halophile Halomonas nitroreducens 11S ${ }^{T}$ (Figure 2 and Table 2) showed the capability to reduce selenite to elemental selenium (González-Domenech et al., 2008).

Halotolerant strains belonging to the phylum Actinobacteria were isolated from marine sediment samples from the Comau Fjord in Northern Patagonia (Undabarrena et al., 2016). These strains showed tolerance to up to $\mathrm{NaCl} 1.7 \mathrm{M}$. Streptomyces sp. $\mathrm{H}-\mathrm{KF} 8$ (Figure 2) tolerates different heavy metals, such as $\mathrm{Ni}$ (15 mM), Cu (0.75 mM), Co (6 mM), Zn (50 mM), Cd (1.5 mM), $\mathrm{Hg}(60 \mu \mathrm{M}), \mathrm{Te}(40 \mu \mathrm{M}), \mathrm{Cr}(20 \mathrm{mM})$, and As (100 mM). The genome sequencing of the Streptomyces sp. H-KF8 strain revealed the presence of 49 heavy metal resistance genes (Undabarrena et al., 2017).

Due to industrial activities or natural sources, saline environments frequently have a high concentration of organic compounds (Castillo-Carvajal et al., 2014; Edbeib et al., 2016). Industrial wastewaters frequently possess high salt concentration, and high levels of organic matter and pollutants, for which a wide variety of conventional biological treatments are not currently suitable (Bonfá et al., 2011). The presence of high levels of aromatic compounds in saline wastewater during crude

TABLE 2 | Halophiles isolated from diverse extreme environments in Chile and their bioremediation potential.

\begin{tabular}{|c|c|c|c|c|c|}
\hline Strain & $\begin{array}{l}\text { GenBank accession } \\
\text { number }\end{array}$ & Isolation source & $\begin{array}{l}\text { Salt } \\
\text { tolerance (M) }\end{array}$ & $\begin{array}{l}\text { Bioremediation } \\
\text { potential }\end{array}$ & Reference \\
\hline Haloferax sp. CL47 & HQ438281 & Cahuil Lagoon & 3.4 & $\begin{array}{l}\text { Naphthalene, } \\
\text { anthracene, } \\
\text { phenanthrene, pyrene, } \\
\text { and benzanthracene } \\
\text { degradation }\end{array}$ & Bonfá et al., 2011 \\
\hline Halomonas nitroreducens $11 S^{\top}$ & EF613113 & Cahuil Lagoon & $0.5-3.4$ & Selenite reduction & González-Domenech et al., 2008 \\
\hline Shewanella sp. Asc-3 & EF157293 & Ascotán salt flat & $0-0.5$ & Arsenic precipitation & Demergasso et al., 2007 \\
\hline Shewanella sp. CC-1 & EF157294 & & & & \\
\hline Exiguobacterium sp. SH31 & LYTG01000000 & Huasco Salar & 0.4 & Arsenic resistance & Castro-Severyn et al., 2017 \\
\hline Microbacterium sp. CGR1 & CP012299 & Alto Andino, Atacama Desert & $0-1.2$ & Arsenic resistance & Mandakovic et al., 2015 \\
\hline
\end{tabular}


oil extraction has been described (Le Borgne et al., 2008). The biodegradation of hydrocarbon-derived pollutants in both soils and groundwater is impaired under elevated salt concentration (Lay et al., 2010). Thus, the application of halotolerant pollutantdegrading bacteria is essential for the bioremediation processes in saline environments.

Halophilic microorganisms capable of degrading hydrocarbons, lignocellulosic materials, chlorophenols, formaldehyde, nitroaromatic compounds have been reported (Oren et al., 1992; García et al., 2004). The halophile Halomonas organivorans degrades a wide range of aromatic compounds (García et al., 2004). Halomonas sp. KHS3 is capable to degrade diverse aromatic hydrocarbons and to produce extracellular rhamnolipids (Corti Monzón et al., 2018). Rhamnolipids are biosurfactants that are used for bioremediation and enhanced oil recovery (Rahman et al., 2003; Sachdev and Cameotra, 2013; Sekhon Randhawa and Rahman, 2014). Additionally, halophilic microorganisms capable of degrading lignocellulosic and nitroaromatic substrates, and chlorophenols have been reported (Oren et al., 1992). The applications of halotolerant bacteria for bioremediation of natural and industrial saline environments is an attractive challenge (Edbeib et al., 2016).

Climate change, chemical fertilizers and saline water used for irrigation are increasing salinity in agricultural soils (Valipour, 2014). Salt toxicity is a major restrictive factor in crop productivity and $20 \%$ of the cultivated land worldwide are seriously affected by salinity (Zhu, 2001; Farhangi-Abriz and Nikpour-Rashidabad, 2017). In response to salt stress, reactive oxygen species (ROS) are accumulated in plant tissues, damaging the photosynthetic apparatus and cellular membranes (Bose et al., 2014; Oukarroum et al., 2015). For preserving osmotic and ionic homeostasis under salt stress, plants accumulate osmolytes such a glycine betaine and proline (Farhangi-Abriz and Torabian, 2017). Halophilic and halotolerant microorganisms produce glycine betaine (Lamark et al., 1991) that may protect plants in saline soils. More recent studies have shown that other halotolerant bacterial mechanisms are also involved in plant protection: (i) increase production of extracellular hydrolytic enzymes (Rohban et al., 2009), (ii) increase activity of 1-aminocyclopropane-1carboxylic acid (ACC) deaminase that reduced plant ethylene levels, which are typically increased by salt stress (Siddikee et al., 2010), (iii) increase indole-3-acetic acid (IAA) levels that enables plant to increase nutrient uptake under salt stress (Vacheron et al., 2013). These studies support the potential application of halotolerant plant growth promoting bacteria to protect crops in saline soils.

\section{ALKALIPHILES}

Alkaliphiles are organisms that grow on alkaline habitats ( $\mathrm{pH}>9$ ), usually showing an optimal growth within $\mathrm{pH} \sim 10$ (Horikoshi, 1999). These extremophiles are classified in two main physiological groups: obligate and facultative alkaliphiles. Facultative alkaliphiles are capable of growing in the $\mathrm{pH}$ range of 7.0-9.5, whereas obligate alkaliphiles (e.g., Bacillus krulwichiae) showed an optimal growth between $\mathrm{pH} 10.0$ and 12.0 (Krulwich and Guffanti, 1989). Alkaliphiles may coexist with neutrophilic microorganisms under mild basic $\mathrm{pH}$ conditions, and also live in specific extreme environments.

To cope with high $\mathrm{pH}$, alkaliphile bacteria possess molecular mechanisms, which comprise the activation of both symporter and antiporter systems (Figure 3). Electrochemical gradient of $\mathrm{Na}^{+}$and $\mathrm{H}^{+}$is produced by electrogenic antiporters, and the symporter system allows the uptake of $\mathrm{Na}^{+}$and other solutes into the cells (Krulwich, 1995; Krulwich et al., 1998). The function of cytochrome $c$-552 in electron and $\mathrm{H}^{+}$accumulation enhances the function of terminal oxidation in respiratory system (Matsuno and Yumoto, 2015). These systems enable the influx of protons and solutes inside the cell due to the alteration in the distribution of ions (e.g., $\mathrm{Na}^{+}$), maintaining the hydrosaline homeostasis and thermodynamic stability of the cell. The transporters are controlled, probably by signaling from a transmembrane $\mathrm{pH}$ sensor (Krulwich, 1995).

Diverse alkaliphilic microorganisms, including bacteria belonging to Bacillus, Micrococcus, Pseudomonas, and Streptomyces genera and eukaryotes, such as yeast and filamentous fungi, have been isolated from alkaline environments, including highly alkaline hyper-saline lakes (e.g., Lake Natron, Tanzania) and alkaline soda lakes (e.g., Lake Mono, CA, United States) (Duckworth et al., 1996; Groth et al., 1997; Horikoshi, 1999; Yakimov et al., 2001). Alkaliphiles are also present in highly alkaline enrichments generated by industrial activities (e.g., indigo dye plants) or soils with high alkalinity (e.g., estuaries with long periods of evaporation, clay particles with highly abundant alkaline crevices) (Grant, 2003; Sorokin et al., 2006).

Alkaliphilic microorganisms have been studied as novel sources for several biotechnological applications, including the treatment of highly toxic wastewater (e.g., dye-containing effluents). Textile effluents are characterized by the presence of high salt and alkaline $\mathrm{pH}$ along with the presence of toxic dyes (Maier et al., 2004; Khalid et al., 2012; Prasad and Rao, 2013). Several alkaliphiles have been isolated from these hostile environments and explored as biocatalysts for the treatment of dye-containing effluents (Hou et al., 2017). Nesterenkonia lacusekhoensis EMLA3 that was isolated from a highly alkaline textile effluent ( $\mathrm{pH} \sim 13$ ) degrades the toxic azo dye methyl red in the presence of high salt concentration and heavy metals $(\mathrm{Ni}$ (II), Cr (VI), and Hg (II) (Bhattacharya et al., 2017). Alkaliphilic microorganisms have been applied to remove ammonia from N-rich saline wastewater, mainly produced by coke plants, fuel refining and fertilizer industries. Chemolithoautotrophic alkalophilic microorganisms have been applied to clean up ammonia pollution in effluents (Sheela et al., 2014; Cui et al., 2016). Complete ammonia oxidation into nitrate by bacteria could be useful for waste water treatment and to engineer ecosystems (Lawson and Lücker, 2018).

In Chile, alkaliphiles have been isolated mainly in the Northern Region, specifically along salt deposits from Atacama Desert and Altiplano. This region has aridic to semi-aridic climate regimes and comprises many different (hyper)saline deposits, including evaporitic basins, known as saltflats, and athalassohaline ponds (Chong, 1984; Demergasso 
et al., 2004). Microorganisms in saltflats from Llamará Salar (Central Depression), Atacama Salar (Pre-Andean Depression), Ascotán Salar and Huasco Salar (Altiplano) have been reported (Demergasso et al., 2004; Dorador et al., 2008; Castro-Severyn et al., 2017), revealing insights of the special metabolic capabilities of these alkaliphiles and their responses to multiple stressors. Mandakovic et al. (2018) isolated from Lejía Lake in the Chilean Altiplano Microbacterium sp. CGR2, Planococcus sp. strains ALS7 and ALS8 that are tolerant to $\mathrm{pH} 12$. However, the extremophiles from several alkaline ecosystems in Chile have not been explored. For example, Amarga Lake (Torres del Paine National Park, Patagonia) is a shallow cold lake with hypersaline water and an alkaline $\mathrm{pH}$ of 8.9 (Solari et al., 2004), which should harbor polyextremophile bacteria. However, to date in Amarga Lake only the presence of stromatolites has been reported.

Several heavy metal-resistant alkaliphiles have been isolated in Chile. The microbiota associated to the athalassohaline ecosystem Huasco Salar in the Atacama Desert showed resistance/tolerance to copper, tellurium, and arsenic (Castro-Severyn et al., 2017). Exiguobacterium isolates from this site carry a number of stress-related genetic determinants, including metal/metalloid resistance genes. For example, the arsenic resistant strain Exiguobacterium sp. SH31 has a set of genes encoding proteins required for arsenic resistance, including the arsenic efflux pump Acr3, growing in presence of arsenite $(10 \mathrm{mM})$ and arsenate (100 mM) (Ordoñez et al., 2015; Castro-Severyn et al., 2017). Dorador et al. (2008) analyze ammonia-oxidizing bacteria (AOB) from four sites in Huasco Salar. A phylotype exhibited 98\% sequence similarity to the extremely alkalitolerant ammoniaoxidizing Nitrosomonas europaea/Nitrosococcus mobilis (Squeo et al., 2006; Dorador et al., 2008). AOB play a key role in the nitrogen cycle. Nitrosomonas and Nitrosococcus genera belong to Nitrosobacteria that are AOB involved in the aerobic oxidation of ammonia into nitrite in agricultural soils (Hernández et al., 2011).

Alkaliphiles have been also found in unusual habitats. Quiroz et al. (2015) reported the presence of Halomonas alkaliphila in a brine shrimp Artemia that was collected from salty lagoons scattered in saltflats of the Atacama Desert (Browne, 1980; Abatzopoulos et al., 2002; Riddle et al., 2013; Quiroz et al., 2015). Halomonas alkaliphila is an alkaliphilic halotolerant bacterium that grows aerobically at $\mathrm{pH} 9$, which has been previously isolated from a salt pool located in Montefredane, Italy (Romano et al., 2006). Recently, two Halomonas strains were isolated from Lejía Lake soil in Atacama Desert (Mandakovic et al., 2018). Due to its adaptation to a wide range of salt concentrations and alkaline $\mathrm{pH}$, Halomonas may be useful for the clean up of polluted saline habitats (Berendes et al., 1996). Additional studies of novel alkaliphilic bacteria and archaea are required to understand their metabolism and physiology and to assess their bioremediation potential.

\section{MICROBES IN DRY ENVIRONMENTS}

An increase of dry environments in diverse regions due to low rainfall, high temperatures and drought has been associated to Climate change (Mukherjee et al., 2018). Water is essential for all living organisms (Robinson et al., 2015; Lebre et al., 2017). Arid environments like deserts are considered to be at the dry limit for life (Navarro-González et al., 2003; Bull and Asenjo, 2013). Extremophile xerotolerant organisms can survive in dry environments with water activity $<0.75$ (Connon et al., 2007; Lebre et al., 2017). Water activity is calculated as the ratio of the vapor pressure in an environment relative to pure water, and it is considered to be the amount of water available to organisms in the environment (Lebre et al., 2017). Arid areas are biomes with a ratio of mean annual rainfall to mean annual evaporation of $<0.05 \mathrm{~mm}_{\text {year }}{ }^{-1}$, and $<0.002 \mathrm{~mm} \mathrm{year}^{-1}$ for extreme hyperarid areas (Mohammadipanah and Wink, 2016). In addition to the low rainfall, other factors such as high and low temperatures, low water activity, high salinity, low concentrations of organic carbon and intense radiation intensify the xeric conditions, constraining the survival of microorganisms (Dose et al., 2001; Crits-Christoph et al., 2013).

Xerotolerant bacteria have developed two strategies to survive in dry environments: evasion of environmental stress and adaptative mechanisms (Figure 3). Evasion of dry environmental implies the conversion of cells into a state of non-replicative viability through the formation of spores (Crits-Christoph et al., 2013). Adaptative mechanisms are associated to preventing water loss and increasing water retention through the accumulation of osmoprotectants (trehalose, L-glutamate, glycine betaine), production of extracellular polymeric substances (EPS), modifications on the cell membrane to retain intracellular water, and synthesis of DNA-repair proteins (Dose et al., 2001; Lebre et al., 2017).

The Atacama Desert is the oldest desert on Earth with hyper-arid soils with mean rainfall $<5 \mathrm{~mm} \mathrm{year}^{-1}$ to $2.4 \mathrm{~mm}$ year $^{-1}$ in the Yungay sector (Warren-Rhodes et al., 2006; Azua-Bustos et al., 2015). Nevertheless, microorganisms are capable to inhabit this extreme environment. Previous studies using culture-dependent methods have reported low numbers of bacteria in Atacama Desert soils, ranging from not detectable to $10^{6} \mathrm{CFU}$ per $\mathrm{g}$ of soil, with a high degree of spatial heterogeneity (Crits-Christoph et al., 2013). Analysis through culture-independent methods on the subsurface layers of the hyper-arid core showed limited abundance of microbial communities including Proteobacteria, Actinobacteria, Cyanobacteria, Chloroflexi, Firmicutes, Gemmatimonadetes, Planctomycetes, and Thermomicrobia phyla (Dong et al., 2007; Crits-Christoph et al., 2013; Azua-Bustos et al., 2015; Piubeli et al., 2015; Azua-Bustos et al., 2017).

Proteobacteria from Atacama Desert showed a high bioremediation potential. Pseudomonas arsenicoxydans strain VC-1 isolated from arsenic-polluted site is able to tolerate high concentration of As(III) (5 mM), and also capable of oxidizing As(III) to As(V) at high rates (Campos et al., 2010). Actinobacteria are the most abundant culturable phylum present in Atacama Desert soils, including strains from Streptomyces, Nocardia, Microlunatus, Prauserella, Microcella, Arthrobacter, Cryobacterium, Frigobacterium, Dietzia, Nocardioides, Propionibacterium, Luteococcus, Kocuria, and Patulibacterium genera (Bull and Asenjo, 2013). Actinobacteria plays a relevant ecological role including resistance to heavy 
metals, recycling of substances, degradation of complex polymers and organic persistent pollutants, and synthesis of bioactive molecules (Claverías et al., 2015; Alvarez et al., 2017; Undabarrena et al., 2017), which may explain its capability to still predominate in such harsh environmental conditions. The extreme desiccating condition of deserts has been the main driving force in the evolution of several desert-derived Actinobacteria, which showed a wide range of biotechnological applications including the removal of organic and inorganic pollutants (Mohammadipanah and Wink, 2016; Alvarez et al., 2017). Chilean desert-Actinobacteria research has focused on obtaining microorganisms able to synthesize novel bioactive molecules (Bull and Asenjo, 2013; Azua-Bustos and GonzálezSilva, 2014). Xerotolerant Streptomyces bulli and S. atacamensis synthesize ansamycin and 22-membered macrolactones with antibacterial and antitumor activities (Santhanam et al., 2013; Mohammadipanah and Wink, 2016). However, the potential of Atacama Desert-Actinobacteria toward bioremediation of pollutants and waste treatment remained underexplored.

As Atacama Desert conditions are too dry to support higher plants and most other photoautotrophic microorganisms, it gathers multiple features to ensure proliferation of primary producers. It has been shown that translucent rocks served as "refuge" for photosynthetic microbial communities, that are capable to colonize the underside of the rocks, where sufficient moisture depending of fog and dew is retained, and light intensities are not lethal. Indeed, hypolithic cyanobacteria are present in small spatially isolated islands on hyper arid Atacama Desert soil (Dong et al., 2007). These hypolithic Cyanobacteria communities are composed mainly of the Chroococcidiopsis genus, which is one of the most primitive representant of the phylum (Warren-Rhodes et al., 2006). Chroococcidiopsis strains are members of the hydrocarbon-degrading biofilms during bioremediation of hydrocarbon pollutants in aquatic environments (Al-Bader et al., 2013). Although Atacama Cyanobacteria has not been used in bioremediation processes, the use of xerotolerant bacteria of dry environments is an attractive strategy for bioremediation under hydric resource limitation.

Desertification and the demand for residential space in sites with water availability limitation have caused an increase of pollution in dry environments. Therefore, technologies for the bioremediation of polluted dry sites are required. Bioremediation of oils spills in desert soils has been reported (Godoy-Faúndez et al., 2008; Benyahia and Embaby, 2016). Strategies to alleviate the xeric stress are relevant to improve bioremediation processes in dry environments. Hereby, xerotolerant bacteria play a crucial role for bioremediation of soils in extreme dry conditions.

\section{UV- AND GAMMA-RESISTANT MICROORGANISMS}

Ultraviolet (UV) light is radiation with a wavelength between 40 and $400 \mathrm{~nm}$. UV radiation is divided into five different ranges: (i) Vacuum UV (40-190 nm), (ii) Far UV (190-220 nm), (iii) Short-wavelength UVC (220-290 nm), (iv) Medium-wavelength UVB (290-320 nm), and (v) Relatively long-wavelength UVA
(320-400 nm) (Marizcurrena et al., 2017). Life without an assured level of radiation is impossible (Pikuta et al., 2007). However, this type of radiation can be one of the most detrimental abiotic factors causing serious damages in organisms at community and cellular levels. On one hand, UV light constrains the microbial diversity and dynamics of ecosystems to only those UV-resistant (micro)organisms. On the other hand, UV radiation can affect cell survival, producing DNA damage and mutations, oxidative stress and protein denaturation (Marizcurrena et al., 2017; Pérez et al., 2017). UVB and UVC are the most harmful radiation to life (Paulino-Lima et al., 2016). UVB causes direct and indirect DNA damage. UVC may cause direct DNA damage by the formation of pyrimidine dimers and pyrimidine photoproducts (Marizcurrena et al., 2017). However, UVC is completely filtered by the atmosphere and does not reach the Earth's surface. UVB is mostly filtered by the atmosphere, but in places where the ozone layer is thinner, the protective filter activity of the atmosphere is progressively reduced, causing a higher penetration of UVB radiation (Yang et al., 2008).

In Chile, several places have exposure to extreme solar radiation levels and high doses of UVB due to the ozone layer hole (Cordero et al., 2016; Paulino-Lima et al., 2016; Pérez et al., 2017). Atacama Desert is characterized by its high altitude, prevalent cloudless conditions, extreme dryness, relatively low columns of ozone and water vapor and intense solar UV radiation (Cordero et al., 2016; Paulino-Lima et al., 2016), which converts this desert in a key region for international astrobiology studies. The microorganisms that are capable of living under these extreme conditions are known as UV resistant extremophiles (Gabani et al., 2014). The study of microorganisms living in these hostile environments is currently focused to gain understanding on the origin of life and early evolution on Earth, to develop models for predicting consequences of future Climate change and to exploit their potential for biotechnological applications (Pérez et al., 2017).

Ultraviolet resistant extremophiles have developed different strategies to resistant UV stress (Figure 3). These strategies are related to efficient machinery for DNA-repair, induction of chaperones and active defense against UV-induced oxidative stress (e.g., glutathione accumulation) (Pérez et al., 2017). The capability of these microorganisms to repair DNA damage has been associated to radiation resistance, since it has been suggested that radiotolerant bacteria accumulate high intracellular manganese and reduced iron levels (Pikuta et al., 2007), conferring them resistance to UV radiation (PaulinoLima et al., 2016). These types of microorganisms are usually polyextremophiles, since it has been noticed that DNA damage that accumulates during desiccation is critical also for desiccation tolerance (Mattimore and Battista, 1996).

Novel species of the genus Deinococcus has been isolated, mainly from environments with high UV radiation, such as deserts and arctic zones (Hirsch et al., 2004; Rainey et al., 2005; Bruch et al., 2015; Guerra et al., 2015). Strains isolated from these environments have been proposed as biocatalysts for bioremediation of radioactive waste sites (Daly, 2000; Mrazek, 2002; Ghosal et al., 2005). UV resistant strains of the Deinococcus genus have been associated to 
radiation resistance (Cox and Battista, 2005). D. radiodurans has been engineered for bioremediation of heavy metals and persistent organic pollutants (Daly, 2000; Cox and Battista, 2005). Deinococcus peraridilitoris strains KR-196, KR-198 and KR-200t (Table 1) were isolated from an arid desert soil collected in the north of Antofagasta, Chile. These isolates showed a high tolerance to ionizing radiation $>10 \mathrm{kGy}$, radiation even higher than reported for the model Deinococcus radiodurans strain R1 (10 kGy) (Cox and Battista, 2005; Rainey et al., 2007). Deinococcus sp. UDEC-P1 was isolated in Témpanos Lake, an oligotrophic lake in the Chilean Patagonia (Guerra et al., 2015). Due to their natural resistance to high levels of radiation, Deinococcus species isolated in Chile are potential candidates for bioremediation of radioactive wastes and environments.

High altitude lakes have the potential to be fertile niche for the isolation of novel UV-resistant microorganisms with potential for bioremediation processes. Escudero et al. (2007) have studied the diversity of microorganisms of high lakes Aguas Calientes (5,870 $\mathrm{m}$ above sea level) and Licancabur (5,916 $\mathrm{m}$ above sea level) located in the Northern Andes of Chile. These areas have high rates of UVB radiation (48.5 $\mathrm{MW} / \mathrm{cm}^{2}$ ). Analysis of sediments and brine of Aguas Calientes lake show that the microorganisms belong mainly to the phylum Proteobacteria, and $70 \%$ of the sequences could not be assigned to a phylogenetic group. Licancabur Lake showed a dominance of Cytophaga-Flavobacteria-Bacteroidetes and Proteobacteria. Plankton analysis of Licancabur Lake shows poor diversity and abundance in water samples, reporting Cyanobacteria, Chrysophyceae, Euglenophyta, and Chlorophyceae strains (Albarracín et al., 2015). In spite of these pioneering reports, the microbial communities and UV-resistant microorganisms of Chilean sites with extreme solar radiation levels such as high altitude deserts and lakes and Antarctica are still mainly unknown.

\section{PSYCHROPHILES}

Psychrophiles refer to microbes that are capable to grow at temperatures ranging from -20 to $20^{\circ} \mathrm{C}$, with an optimal growth temperature of $<15^{\circ} \mathrm{C}$ (Morita, 1975; Clarke et al., 2013). Psychrophilic bacteria possess diverse molecular mechanisms to survive at low temperatures (Figure 3). On one side, an increase of unsaturated fatty acids, cyclopropane-containing fatty acids and short chain fatty acids in membranes prevents the loss of membrane fluidity (Feller and Gerday, 2003; D'Amico et al., 2006). A second mechanisms is the high synthesis of coldshock proteins (CSPs) and chaperones that protect the synthesis of RNA and proteins (Godin-Roulling et al., 2015). A third mechanism is the synthesis of anti-freeze proteins (AFPs) that binds to ice crystals and generates a state of thermal hysteresis (Kristiansen and Zachariassen, 2005; Muñoz et al., 2017). A fourth mechanism is the accumulation of mannitol and other compatible solutes as cryo-protectants to prevent cell damage by UV radiation. An additional mechanism is the transport of compatible solutes such as mannitol to stabilize the cytoplasmatic environment and prevent ice formation (Baraúna et al., 2017). Nevertheless, the most general mechanism is the adaptation of psychrophilic enzymes through inherent modifications of their primary structure. Some of these amino acid changes are minimal in comparison with mesophilic proteins, playing a role in catalytic regions or stabilization of the proteins (Feller and Gerday, 2003; D'Amico et al., 2006; Cavicchioli et al., 2011).

In Chile, psychrophiles have been isolated from several cold environments, such as the high mountains of Los Andes Mountain, vast ice regions, such as the Northern and Southern Ice Field, Southern extreme zones, such as the Patagonia, and the Antarctic continent. Antarctica became a subject of intense research in several fields, including the exploration of novel microbes and their pigments, antibiotics and enzymes. The development of special research programs that supports long-timed expedition logistics have facilitated the access of researchers and increase the research on the Antarctica (Loperena et al., 2012; Órdenes-Aenishanslins et al., 2016; Lavin et al., 2017). However, in-depth research conducted on psychrophiles in cold environments, such as a report in Alpine glacier (Ferrario et al., 2017), remain to be conducted.

Antarctica plays also a huge role in two mainstream research topics, global Climate change and global contamination assessment. The pollution in Antarctica is partly explained by the grasshopper effect: pollutants are moved across the globe in the atmosphere without suffering major changes and are later deposited in continuous-forming ice sheets across Antarctica surface. Other pollution source on Antarctica resides on human activity from military and scientific bases (ASOC, 2007). The detection of diverse organic and inorganic contaminants in Antarctic territory is of increasing concern. Since Antarctica is a region where the introduction of foreign microorganisms is forbidden, the only strategy for bioremediation processes is the application of native microbes (Poland et al., 2003; Gran-Scheuch et al., 2017).

Bacteria capable to degrade crude oil at low temperatures even below the freezing point have been reported (Gerdes et al., 2005; Bowman and Deming, 2014). Alkane hydroxylases are key enzymes for the degradation of alkanes, activating them through conversion into alcohols (van Beilen and Funhoff, 2007; Fuentes et al., 2014). A survey of alkane hydroxylases genes in psychrophilic bacteria reveals the adaptability of these proteins, giving valuable insights on the degradation of long chain hydrocarbons at low temperature. Mostly enzymes were related to the $\mathrm{AlkB}$ and cytochrome P450 alkane hydroxylases, but also LadA and AlmA enzymes involved in long-chain alkanes degradation were reported (Bowman and Deming, 2014). The primary structure of psychrophile enzymes differ from their mesophile homologs in the preferences for specific amino acids and increased flexibility on loops, bends, and $\alpha$-helices. Notably, various novel genes were reported from Psychrobacter, Octadecabacter, Glaciecola, Terriglobus and Photobacter genera (Bowman and Deming, 2014). Obligated hydrocarbonoclastic microorganisms (i.e., microbes that use exclusively hydrocarbons as carbon sources) isolated near to Antarctic coast have been described. For example, Oleispira antarctica, whose genome 
reveals a diversity of alkane degradation genes and a system of proteins that acts as cold barrier to circumvent low temperature effects that could stop hydroxylase reaction (Kube et al., 2013).

Studies performed in the Chilean Antarctic territory are mainly focused on Fildes Peninsula, where the human activity in scientific and military bases had caused several contamination events, including hydrocarbon spills. The estimation of the polluted area impacted is about $3.5 \mathrm{~km}^{2}$, corresponding to $12 \%$ of the total area of the Peninsula (ASOC, 2007). However, bioremediation plans for these sites have not yet been reported. Remarkably, the hydrocarbon degradation potential of native microorganisms from the near Argentinian Carlini Station has been described. Polaromonas naphthalenivorans, a strain capable of naphthalene degradation and $\mathrm{N}_{2}$ fixation, and strains belonging to Nocardioides genus were dominant in soils with higher hydrocarbon pollution (Vázquez et al., 2017). The hydrocarbonoclastic strains Rhodococcus sp. D32AFA, Pseudomonas sp. E43FB and Sphingobium sp. D43FB that degrade phenanthrene were isolated from diesel contaminated Antarctic soils (Gran-Scheuch et al., 2017). The Antarctic soil strain Streptomyces sp. So3.2 is able to produce a biosurfactant, which may be useful for hydrocarbon bioremediation (Lamilla et al., 2018).

Psychrophiles seem to be naturally adapted to cope with a wide-range of heavy metals in the environment (De Souza et al., 2006; Tomova et al., 2015; Gonzalez-Aravena et al., 2016). This adaptive trait may be explained by the presence of heavy metals in Antarctica's sediments. In addition a high occurrence of plasmids in Antarctic bacteria has been reported, which are probably related to the transfer of resistance/tolerance genes to heavy metals such as mercury, tellurium, cadmium, copper, chromium, and lead (Mangano et al., 2013; Gonzalez-Aravena et al., 2016; Rodriguez-Rojas et al., 2016a). Interestingly, a high proportion of these bacterial isolates are multiple heavy metalresistant bacteria. Mercury- and tellurite-resistant strains were isolated from Greenwich Island (Rodriguez-Rojas et al., 2016b). Pseudomonas putida strain ATH-43 (Figure 2 and Table 2) revealed high tolerance to cadmium, copper, chromium, and selenium, whereas Psychrobacter sp. ATH-62 is resistant to mercury and tellurite (Rodriguez-Rojas et al., 2016a). Heavy metal-resistant bacteria were also isolated from invertebrates from the Antarctic shores. Mercury-resistant Pseudoalteromonas sp. gw196 and Colwellia sp. gw172, and zinc and cadmiumresistant Arthrobacter and Psychrobacter strains were isolated from a marine sponge (Mangano et al., 2013). Flavobacterium and Psychrobacter strains with resistance to mercury and zinc were isolated from a sea urchin (Gonzalez-Aravena et al., 2016).

Antarctic bacteria have been also studied for additional biotechnological applications. An Antarctic psychrophilic Pseudomonas strain was able to produce quantum dots from Cd salts (Gallardo et al., 2014). A psychrophilic Pseudomonas mandelli able to produce alginate has also been reported (Bayat et al., 2015; Vasquez-Ponce et al., 2017). Alginate is useful to encapsulate microbes to improve the bioremediation of persistent organic pollutants such as pesticides in polluted soils (Morgante et al., 2010). Encapsulation of microbes in alginate beads may prevent stress or predation of the inocula (Morgante et al., 2010).

The diversity of bacteria from the Antarctica that showed wide range heavy metal resistance and hydrocarbon degradation capabilities revealed a complex community that include adapted cosmopolitan bacteria such as Pseudomonas and other native strains, which may be useful for bioremediation in cold environments.

\section{CONCLUDING REMARKS AND FUTURE PERSPECTIVES}

Chile has been referred to be a "biogeographic island" due to a succession of natural barriers, including Altiplano, Atacama Desert, Los Andes Mountains, South Pacific Ocean, Patagonia, and Antarctica. Geological processes and climatic conditions have driven the current geography of Chile into a set of diverse ecosystems that reassemble heaven for both extremophilic and polyextremophilic microorganisms. Those biotopes include a multiplicity of ecosystems with more than one extreme environmental condition, such a high salinity, low humidity, high UV radiation, high or low temperature, high or low $\mathrm{pH}$, and high concentration of heavy metals. These extreme environmental conditions exert a strong pressure limiting the biodiversity of each niche, since every condition is associated with its own set of adaptations for stability on its environment. At specie-level, microbes that are capable to persist in such (multi) extreme conditions gather (multiple) metabolic capabilities that are not present in mesophilic microbes, and thus, represent a great potential for biotechnological and environmental applications (Liu et al., 2018). At an ecological level, it has been previously shown that microbial communities in extreme environments evolved at a faster rate than mesophiles living in benign environments, highlighting particularities of the evolutionary dynamic of such environments (Li et al., 2014). For these reasons, diverse research efforts have been initially focused on analyzing natural microbial communities of those sites and studying physiological and genomic characteristics of the microbial isolates.

Next generation sequencing (NGS) and next generation proteomics (NGPs) provide powerful techniques to gain insights about the molecular mechanisms involved in microbial adaptation to extreme conditions (Armengaud, 2016). These type of studies and methods will reveal the mechanisms and strategies used by microbes to adapt to extreme conditions and are useful to understand the evolution of microorganisms subjected to extreme conditions.

In recent years, there are significant advances in the field of extremophiles at the global level. Similar trend has also been reported by researchers from Chile, whose discoveries have made the field to flourish. This progress relied upon the advances of physico-chemical characterization of those biotopes together with the advent of high-throughput molecular tools to understand the complexity of microbial communities and improved tools and techniques for microbial isolation. Many of those studies have gained significant insights on the 
molecular mechanisms involved in extremophiles' adaptations to extreme environments and their co-evolutionary processes, and also contributed to current biotechnological developments, such as Swissaustral, a company with headquarters in Chile, which performs functional enzymatic screening for industrial and biotechnological applications (Blamey et al., 2017). Additional research efforts must be invested into broadening the taxonomic breadth of extremophiles and expanding towards the study of extremolyes, metabolites utilized as biological defense mechanisms to combat extreme environmental stresses (such as ectoine).

The restoration of polluted environment is a crucial task for sustainable development. For the clean up of polluted sites, bioremediation is an attractive alternative to physicochemical treatment processes. Microbes are main catalysts for the bioremediation of polluted environments. Extremophiles has been isolated in diverse zones in Chile that possess extreme conditions such as Altiplano, Atacama Desert, Central Chile, Patagonia, and Antarctica. Interestingly, the remarkable adaptative capabilities of extremophiles convert these organisms into an attractive source of catalysts for bioremediation and industrial processes.

Future research will carry out more detailed studies on extremophiles already described in order to deepen their knowledge and optimize their use in industrial processes including bioremediation. On the other side, a large number of extreme environments in Chile are still unexplored or underexplored. These habitats harbor microbial communities with metabolic capabilities useful for bioremediation processes and other applications. Therefore, future research should focus on the isolation, identification and characterization of a higher number of extremophiles from ecosystems with extreme conditions. Thereafter, studies should explore the metabolic potential of microbial isolates for application in biotechnology including the bioremediation of heavy metals and persistent organic pollutants. The basic research on

\section{REFERENCES}

Abatzopoulos, T., Kappas, I., Beardmore, J., Clegg, J. S., and Sorgeloos, P. (2002). Artemia: Basic and Applied Biology. Dorcrecht: Kluwer Academic Publishers. doi: 10.1007/978-94-017-0791-6

Acosta, M., Galleguillos, P. A., Guajardo, M., and Demergasso, C. (2017). Microbial survey on industrial bioleaching heap by high-throughput $16 \mathrm{~S}$ sequencing and metagenomics analysis. Solid State Phenom. 266, 219-223. doi: 10.4028/www. scientific.net/SSP.262.219

Aguayo, P., Gonzáles, P., Campos, V., Maugeri, T. L., Papale, M., Gugliandolo, C., et al. (2017). Comparison of prokaryotic diversity in cold, oligotrophic remote lakes of Chilean Patagonia. Curr. Microbiol. 74, 598-613. doi: 10.1007/s00284017-1209-y

Aguilar, A., Ingemansson, T., and Magniea, E. (1998). Extremophile microorganisms as cell factories: support from the European Union. Extremophiles 2, 367-373. doi: 10.1007/s007920050080

Ahring, B. K. (1995). Methanogenesis in thermophilic biogas reactors. Antonie Van Leeuwenhoek 67, 91-102. doi: 10.1007/BF00872197

Al-Bader, D., Kansour, M. K., Rayan, R., and Radwan, S. S. (2013). Biofilm comprising phototrophic, diazotrophic, and hydrocarbon-utilizing bacteria: a promising consortium in the bioremediation of aquatic hydrocarbon pollutants. Environ. Sci. Pollut. Res. Int. 20, 3252-3262. doi: 10.1007/s11356012-1251-Z extremophiles combined with the scale up of the biotechnological process including bioremediation and waste treatments will offer a bright future to Chilean economy and an increasing welfare to its inhabitants.

\section{DEDICATION}

This article is dedicated to the memory of Professor Dr. Burkhard Seeger Stein (1929-2016), who inspired the study of natural resources in Chile through his pioneering research and teaching.

\section{AUTHOR CONTRIBUTIONS}

RO, CM, GB, FD, AC, RV, CR, and MS wrote and discussed the article.

\section{ACKNOWLEDGMENTS}

The authors gratefully acknowledge Pedro Serrano, Alejandra Pemjean, Enrique Bialoskorski, Michael Seeger, and Sebastian Fuentes for the landscape photographies shown in Figure 1. The authors acknowledge Conicyt Ph.D. fellowships (CM, FD, and GB) and financial support of CONICYT Programa de Investigación Asociativa (PIA) Anillo ACT172128 GAMBIO (MS), FONDECYT 1151174 (http://www.fondecyt.cl) (MS), USM (http://www.usm.cl) (MS), CONICYT/PAI Concurso Nacional de Apoyo al Retorno de Investigadores desde el Extranjero 82140028 (http://www.conicyt.cl) (RO and MS), and Apoyo a la Formación de Redes Internacionales para Investigadores en Etapa Inicial 170600 (http://www.conicyt.cl) (RO and MS). The funders had no role in study design, data collection and analyses, decision to publish, or preparation of the manuscript.

Albarracín, V. H., Kurth, D., Ordoñez, O. F., Belfiore, C., Luccini, E., Salum, G. M., et al. (2015). High-Up: a remote reservoir of microbial extremophiles in Central Andean wetlands. Front. Microbiol. 6:1404. doi: 10.3389/fmicb.2015.01404

Alcamán, M. E., Alcorta, J., Bergman, B., Vásquez, M., Polz, M., and Díez, B. (2017). Physiological and gene expression responses to nitrogen regimes and temperatures in Mastigocladus sp. strain CHP1, a predominant thermotolerant cyanobacterium of hot springs. Syst. Appl. Microbiol. 40, 102-113. doi: 10.1016/ j.syapm.2016.11.007

Alcamán, M. E., Fernández, C., Delgado, A., Bergman, B., and Díez, B. (2015). The cyanobacterium Mastigocladus fulfills the nitrogen demand of a terrestrial hot spring microbial mat. ISME J. 9. 2290-2303. doi: 10.1038/ismej. 2015.63

Alvarez, A., Saez, J. M., Costa, J. S. D., Colin, V. L., Fuentes, M. S., Cuozzo, S. A., et al. (2017). Actinobacteria: current research and perspectives for bioremediation of pesticides and heavy metals. Chemosphere 166, 41-62. doi: 10.1016/j.chemosphere.2016.09.070

Amaro, A. M., Chamorro, D., Seeger, M., Arredondo, R., Peirano, I., and Jerez, C. A. (1991). Effect of external $\mathrm{pH}$ perturbations on in vivo protein synthesis by the acidophilic bacterium Thiobacillus ferrooxidans. J. Bacteriol. 173, 910-915. doi: 10.1128/jb.173.2.910-915.1991

Antranikian, G., Vorgias, C. E., and Bertoldo, C. (2005). Extreme environments as a resource for microorganisms and novel biocatalysts. Adv. Biochem. Eng. Biotechnol. 96, 219-262. doi: 10.1007/b135786 
Armengaud, J. (2016). Next-generation proteomics faces new challenges in environmental biotechnology. Curr. Opin. Biotechnol. 38, 174-182. doi: 10.1016/j.copbio.2016.02.025

Armijo, R., Lacassin, R., Coundurier-Curveur, A., and Carrizo, D. (2015). Coupled tectonic evolution of Andean orogeny and global climate. Earth Sci. Rev. 143, 1-35. doi: 10.1016/j.earscirev.2015.01.005

Arulazhagan, P., Al-Shekri, K., Huda, Q., Godon, J. J., Basahi, J. M., and Jeyakumar, D. (2017). Biodegradation of polycyclic aromatic hydrocarbons by an acidophilic Stenotrophomonas maltophilia strain AJH1 isolated from a mineral mining site in Saudi Arabia. Extremophiles 21, 163-174. doi: 10.1007/ s00792-016-0892-0

ASOC (2007). Implementation the Madrid Protocol: a case study of Fildes Peninsula, King George Island. Paper Presented at the XXX Antarctic Treaty Consultative Meeting, 30 April - 11 May 2007, New Delhi.

Asta, M. P., Cama, J., Martínez, M., and Giménez, J. (2009). Arsenic removal by goethite and jarosite in acidic conditions and its environmental implications. J. Hazard. Mater. 171, 965-972. doi: 10.1016/j.jhazmat.2009.06.097

Azua-Bustos, A., Caro-Lara, L., and Vicuña, R. (2015). Discovery and microbial content of the driest site of the hyperarid Atacama Desert, Chile. Environ. Microbiol. Rep. 7, 388-394. doi: 10.1111/1758-2229.12261

Azua-Bustos, A., and González-Silva, C. (2014). Biotechnological applications derived from microorganisms of the Atacama Desert. Biomed. Res. Int. 2014:909312. doi: 10.1155/2014/909312

Azua-Bustos, A., González-Silva, C., and Corsini, G. (2017). The hyperarid core of the Atacama Desert, an extremely dry and carbon deprived habitat of potential interest for the field of carbon science. Front. Microbiol. 8:993. doi: 10.3389/ fmicb.2017.00993

Ballantyne, J. M., and Moore, J. N. (1988). Arsenic geochemistry in geothermal systems. Geochim. Cosmochim. Acta 52, 475-483. doi: 10.1016/0016-7037(88) 90102-0

Baraúna, R. A., Freitas, D. Y., Pinheiro, J. C., Folador, A. R. C., and Silva, A. (2017). A proteomic perspective on the bacterial adaptation to cold: integrating OMICs data of the psychrotrophic bacterium Exiguobacterium antarcticum B7. Proteomes 5:E9. doi: 10.3390/proteomes5010009

Barbieri, R., and Cavalazzi, B. (2014). How do modern extreme hydrothermal environments inform the identification of martian habitability? The case of the El Tatio Geyser field. Challenges 5:430. doi: 10.3390/challe50 20430

Bayat, Z., Hassanshahian, M., and Cappello, S. (2015). Immobilization of microbes for bioremediation of crude oil polluted environments: a mini review. Open Microbiol. J. 9, 48-54. doi: 10.2174/18742858015090 10048

Benyahia, F., and Embaby, A. S. (2016). Bioremediation of crude oil contaminated desert soil: effect of biostimulation, bioaugmentation and bioavailability in biopile treatment systems. Int. J. Environ. Res. Public Health 13:219. doi: $10.3390 /$ ijerph 13020219

Beolchini, F., Dell'Anno, A., Rocchetti, L., Vegliò, F., and Danovaro, R. (2009). Biohydrometallurgy as a remediation strategy for marine sediments contaminated by heavy metals. Adv. Mat. Res. 71, 669-672. doi: 10.4028/www. scientific.net/AMR.71-73.669

Berendes, F., Gottschalk, G., Heine-Dobbernack, E., Moore, E. R. B., and Tindall, B. J. (1996). Halomonas desiderata sp.nov, a new alkaliphilic, halotolerant and denitrifying bacterium isolated from a municipal sewage works. Microbiology 19, 158-167. doi: 10.1016/S0723-2020(96)80041-5

Berenguer, J. (2011). "Thermophile," in Encyclopedia of Astrobiology, eds M. Gargaud, R. Amils, and J. C. Quintanilla. (Berlin: Springer), 1666-1667. doi: 10.1007/978-3-642-11274-4_1583

Bernard, G., Pathmanathan, J. S., Lannes, R., Lopez, P., and Bapteste, E. (2018). Microbial dark matter investigations: how microbial studies transform biological knowledge and empirically sketch a logic of scientific discovery. Genome Biol. Evol. 10, 707-715. doi: 10.1093/gbe/evy031

Bhattacharya, A., Goyal, N., and Gupta, A. (2017). Degradation of azo dye methyl red by alkaliphilic, halotolerant Nesterenkonia lacusekhoensis EMLA3: application in alkaline and salt-rich dyeing effluent treatment. Extremophiles 21, 479-490. doi: 10.1007/s00792-017-0918-2

Blamey, J. M., Fischer, F., Meyer, H. P., Sarmiento, F., and Zinn, M. (2017). "Chapter 14: enzymatic biocatalysis in chemical transformations: a promising and emerging field in green chemistry practice," in Biotechnology of Microbial Enzymes ed. G. Brahmachari (London: Elsevier Science).
Bonfá, M. R. L., Grossman, M. J., Mellado, E., and Durrant, L. R. (2011). Biodegradation of aromatic hydrocarbons by Haloarchaea and their use for the reduction of the chemical oxygen demand of hypersaline petroleum produced water. Chemosphere 84, 1671-1676. doi: 10.1016/j.chemosphere.2011. 05.005

Bose, J., Rodrigo-Moreno, A., and Shabala, S. (2014). ROS homeostasis in halophytes in the context of salinity stress tolerance. J. Exp. Bot. 65, 1241-1257. doi: $10.1093 /$ jxb/ert430

Bowman, J. S., and Deming, J. W. (2014). Alkane hydroxylase genes in psychrophile genomes and the potential for cold active catalysis. BMC Genomics 15:1120. doi: 10.1186/1471-2164-15-1120

Bravo, G. (2017). Bioremediation of Mercury Polluted Agricultural Soils Using Cupriavidus Metallidurans MSR33 in a Rotary Drum Reactor and its Effects on Microorganisms Involved in the Nitrogen Cycle. Ph.D. thesis, Universidad Técnica Federico Santa María, Pontificia Universidad Católica de Valparaíso, Valparaíso.

Brock, T. D., Brock, K. M., Belly, R. T., and Weiss, R. L. (1972). Sulfolobus: a new genus of sulfur-oxidizing bacteria living at low $\mathrm{pH}$ and high temperature. Arch. Microbiol. 84, 54-68. doi: 10.1007/BF00408082

Browne, R. A. (1980). Acute response versus reproductive performance in five strains of brine shrimp exposed to copper sulphate. Mar. Environ. Res. 3, 185-193. doi: 10.1016/0141-1136(80)90026-4

Bruch, E. M., De Groot, A., Un, S., and Tabares, L. C. (2015). The effect of gamma-ray irradiation on the Mn (II) speciation in Deinococcus radiodurans and the potential role of Mn (II)-orthophosphates. Metallomics 7, 908-916. doi: 10.1039/C5MT00009B

Bull, A. T., and Asenjo, J. A. (2013). Microbiology of hyper-arid environments: recent insights from the Atacama Desert, Chile. Antonie Van Leeuwenhoek 103, 1173-1179. doi: 10.1007/s10482-013-9911-7

Bustos, S., Castro, S., and Montealegre, R. (1993). The Sociedad Minera Pudahuel bacterial thin-layer leaching process at Lo Aguirre. FEMS Microbiol. Rev. 11, 231-235. doi: 10.1111/j.1574-6976.1993.tb00289.x

Cabrera, G., Viera, M., Gomez, J. M., Cantero, D., and Donati, E. (2007). Bacterial removal of chromium (VI) and (III) in a continuous system. Biodegradation 18, 505-513. doi: 10.1007/s10532-006-9083-5

Campos, V. L., Escalante, G., Yañez, J., Zaror, C. A., and Mondaca M. A. (2009). Isolation of arsenite-oxidizing bacteria from a natural biofilm associated to volcanic rocks of Atacama Desert, Chile. J. Basic Microbiol. 49, S93-S97. doi: 10.1002/jobm.200900028

Campos, V. L., Valenzuela, C., Yarza, P., Kämpfer, P., Vidal, R., Zaror, C., et al. (2010). Pseudomonas arsenicoxydans sp nov., an arsenite-oxidizing strain isolated from the Atacama desert. Syst. Appl. Microbiol. 33, 193-197. doi: 10. 1016/j.syapm.2010.02.007

Canganella, F., and Wiegel, J. (2011). Extremophiles: from abyssal to terrestrial ecosystems and possibly beyond. Naturwissenschaften 98, 253-279. doi: 10. 1007/s00114-011-0775-2

Carrillo, U., Díaz-Villanueva, V., and Modenutti, B. (2018). Sustained effects of volcanic ash on biofilm stoichiometry, enzyme activity and community composition in North-Patagonia streams. Sci. Total Environ. 621, 235-244. doi: 10.1016/j.scitotenv.2017.11270

Castillo-Carvajal, L. C., Sanz-Martín, J. L., and Barragán-Huerta, B. E. (2014). Biodegradation of organic pollutants in saline wastewater by halophilic microorganisms: a review. Environ. Sci. Pollut. Res. 21, 9578-9588. doi: 10.1007/ s11356-014-3036-z

Castro-Severyn, J., Remonsellez, F., Valenzuela, S. L., Salinas, C., Fortt, J., Aguilar, P., et al. (2017). Comparative genomics analysis of a new Exiguobacterium strain from Salar de Huasco reveals a repertoire of stressrelated genes and arsenic resistance. Front. Microbiol. 8:456. doi: 10.3389/fmicb. 2017.00456

Cavicchioli, R., Charlton, T., Ertan, H., Omar, S. M., Siddiqui, K. S., and Williams, T. J. (2011). Biotechnological uses of enzymes from psychrophiles. Microb. Biotechnol. 4, 449-460. doi: 10.1111/j.1751-7915.2011. 00258.x

Chakravarty, R., and Banerjee, P. C. (2012). Mechanism of cadmium binding on the cell wall of an acidophilic bacterium. Bioresour. Technol. 108, 176-183. doi: 10.1016/j.biortech.2011.12.100

Chatterjee, S. K., Bhattacharjee, I., and Chandra, G. (2010). Biosorption of heavy metals from industrial waste water by Geobacillus thermodenitrificans. J. Hazard. Mater. 175, 117-125. doi: 10.1016/j.jhazmat.2009.09.136 
Chen, G. Q., and Jiang, X. R. (2018). Next generation industrial biotechnology based on extremophilic bacteria. Curr. Opin. Biotechnol. 50, 94-100. doi: 10.1016/j.copbio2017.11.016

Chong, G. (1984). Die Salatre in Nordchile - Geologie. Struk. Geochim. Goetekt Forschung 67:146.

Christel, S., Herold, M., Bellenberg, S., El Hajjami, M., Buetti-Dinh, A., Pivkin, I. V., et al. (2018). Multiomics reveals the lifestyle of the acidophilic, mineral-oxidizing model species Leptospirillum ferriphilum T. Appl. Environ. Microbiol. doi: 10.1128/AEM.02091-17 [Epub ahead of print].

Christen, P., Davidson, S., Combet-Blanc, Y., and Auria, R. (2011). Phenol biodegradation by the thermoacidophilic archaeon Sulfolobus solfataricus 98/2 in a fed-batch bioreactor. Biodegradation 22, 475-484. doi: 10.1007/s10532010-9420-6

Christen, P., Vega, A., Casalot, L., Simon, G., and Auria, R. (2012). Kinetics of aerobic phenol biodegradation by the acidophilic and hyperthermophilic archaeon Sulfolobus solfataricus 98/2. Biochem. Eng. J. 62, 56-61. doi: 10.1016/j. bej.2011.12.012

Cirés, S., Casero, M. C., and Quesada, A. (2017). Toxicity at the edge of life: a review on cyanobacterial toxins from extreme environments. Mar. Drugs 15:233 doi: $10.3390 / \mathrm{md} 15070233$

Clarke, A., Morris, G. J., Fonseca, F., Murray, B. J., Acton, E., and Price, H. C. (2013). A low temperature limit for life on Earth. PLoS One 8:e66207. doi: 10.1371/journal.pone.0066207

Claverías, F. P., Undabarrena, A., González, M., Seeger, M., and Cámara, B. (2015). Culturable diversity and antimicrobial activity of Actinobacteria from marine sediments in Valparaíso bay, Chile. Front. Microbiol. 28:737. doi: 10.3389/fmicb. 2015.00737

Connon, S. A., Lester, E. D., Shafaat, H. S., Obenhuber, D. C., and Ponce, A. (2007). Bacterial diversity in hyperarid Atacama Desert soils. J. Geophys. Res. Biogeosci. 112:G04S17. doi: 10.1029/2006JG000311

Cordero, R. R., Damiani, A., Seckmeyer, G., Jorquera, J., Caballero, M., Rowe, P., et al. (2016). The solar spectrum in the Atacama Desert. Sci. Rep. 6:22457. doi: $10.1038 /$ srep22457

Correa-Llantén, D. N., Muñoz-Ibacache, S. A., Castro, M. E, Muñoz, P. A., and Blamey, J. M. (2013). Gold nanoparticles synthesized by Geobacillus sp. strain ID17 a thermophilic bacterium isolated from Deception Island, Antarctica. Microb. Cell Fact. 12:75. doi: 10.1186/1475-2859-12-75

Corti Monzón, G., Nisenbaum, M., Herrera Seitz, K., and Murialdo, S. E. (2018). New findings on aromatic compounds degradation and their metabolic pathways, the biosurfactant production and motility of the halophilic bacterium Halomonas sp. KHS3. Curr. Microbiol. 75, 1108-1118. doi: 10.1007/s00284018-1497-x

Cox, M., and Battista, J. (2005). Deinococcus radiodurans - the consummate survivor. Nat. Rev. Microbiol. 3, 882-892. doi: 10.1038/nrmicro1264

Crits-Christoph, A., Robinson, C. K., Barnum, T., Fricke, W. F., Davila, A. F., Jedynak, B., et al. (2013). Colonization patterns of soil microbial communities in the Atacama Desert. Microbiome 1:28. doi: 10.1016/j.syapm.2010. 02.007

Cui, Y. W., Zhang, H. Y., Ding, J. R., and Peng, Y. Z. (2016). The effect of salinity on nitrification using halophilic nitrifiers in a sequencing batch reactor treating hypersaline wastewater. Sci. Rep. 6:24825. doi: 10.1038/srep24825

Daly, J. M. (2000). Engineering radiation-resistant bacteria for environmental biotechnology. Curr. Opin. Biotechnol. 11, 280-285. doi: 10.1016/S09581669(00)00096-3

D’Amico, S., Collins, T., Marx, J. C., Feller, G., and Gerday, C. (2006). Psychrophilic microorganisms: challenges for life. EMBO Rep. 7, 385-389. doi: 10.1038/sj. embor.7400662

Darkwah, L., Rowson, N. A., and Hewitt, C. J. (2005). Laboratory scale bioremediation of acid mine water drainage from a disused tin mine. Biotechnol. Lett. 27, 1251-1257. doi: 10.1007/s10529-005-3201-Z

De Los Rios-Escalante, P., and Gajardo, G. (2010). Potential heterogeneity in crustacean zooplankton assemblages in southern Chilean saline lakes. Braz. J. Biol. 70, 1031-1032. doi: 10.1590/S1519-69842010000500016

De Souza, M. J., Nair, S., Loka Bharathi, P. A., and Chandramohan, D. (2006). Metal and antibiotic-resistance in psychrotrophic bacteria from Antarctic Marine waters. Ecotoxicology 15, 379-384. doi: 10.1007/s10646-0060068-2

Deive, F. J., Domínguez, A., Barrio, T., Mosocoso, F., Morán, P., Longo, M. A., et al. (2010). Decolorization of dye reactive black 5 by newly isolated thermophilic microorganisms from geothermal sites in Galicia (Spain). J. Hazard. Mater. 182, 735-742. doi: 10.1016/j.jhazmat.2010.06.096

Demergasso, C., Casamayor, E. O., Chong, G., Galleguillos, P., Escudero, L., and Pedrós-Alío, C. (2004). Distribution of prokaryotic genetic diversity in athalassohaline lakes of the Atacama Desert, Northern Chile. FEMS Microbiol. Ecol. 48, 57-69. doi: 10.1016/j.femsec.2003.12.013

Demergasso, C., Galleguillos, F., Soto, P., Serón, M., and Iturriaga, V. (2010). Microbial succession during a heap bioleaching cycle of low grade copper sulfides: does this knowledge mean a real input for industrial process design and control? Hydrometallurgy 104, 382-390. doi: 10.1016/j.hydromet.2010.04.016

Demergasso, C. S., Castillo, D., and Casamayor, E. O. (2005). Molecular characterization of microbial populations in a low-grade copper ore bioleaching test heap. Hydrometallurgy 80, 241-253. doi: 10.1016/j.hydromet.2005. 07.013

Demergasso, C. S., Chong, D. G., Escudero, G. L., Mur, J. J. P., and PedrósAlió, C. (2007). Microbial precipitation of arsenic sulfides in Andean salt flats. Geomicrobiol. J. 24, 111-123. doi: 10.1080/01490450701266605

Dennett, G. V., and Blamey, J. M. (2016). A new thermophilic nitrilase from an antarctic hyperthermophilic microorganism. Front. Bioeng. Biotechnol. 4:5. doi: $10.3389 /$ fbioe. 2016.00005

Diaby, N., Dold, B., Pfeifer, H. R., Holliger, C., Johnson, D. B., and Hallberg, K. B. (2007). Microbial communities in a porphyry copper tailings impoundment and their impact on the geochemical dynamics of the mine waste. Environ. Microbiol. 9, 298-307. doi: 10.1111/j.1462-2920.2006.01138.x

Dong, H., Rech, J. A., Jiang, H., Sun, H., and Buck, B. J. (2007). Endolithic cyanobacteria in soil gypsum: occurrences in Atacama (Chile), Mojave (United States), and Al-Jafr Basin (Jordan) Deserts. J. Geophys. Res. 112:G02030. doi: 10.1029/2006JG000385

Dorador, C., Vila, I., Remonsellez, F., Imhoff, J. F., and Witzel, K. P. (2010). Unique clusters of archea in Salar de Huasco, an athalassohaline evaporitic basin of the Chilean Altiplano. FEMS Microbiol. Ecol. 73, 291-302. doi: 10.1111/j.15746941.2010.00891.x

Dorador, C. I. (2007). Microbial Communities in High Altitude Altiplanic Wetlands in Northern Chile: Phylogeny, Diversity and Function. Ph.D. thesis, ChristianAlbrechts-Universität, Kiel.

Dorador, C., Busekow, A., Vila, I., Imhoff, J., and Witzel, K. P. (2008). Molecular analysis of enrichment cultures of ammonia oxidizers from the Salar de Huasco, a high altitude saline wetland in northern Chile. Extremophiles 12, 405-414. doi: 10.1007/s00792-008-0146-x

Dose, K., Bieger-Dose, A., Ernst, B., Feister, U., Gómez-Silva, B., Klein, A., et al. (2001). Survival of microorganisms under the extreme conditions of the Atacama Desert. Orig. Life Evol. Biosph. 31, 287-303. doi: 10.1023/A: 1010788829265

Duckworth, A. W., Grant, W. D., Jones, B. E., and Vansteenbergen, R. (1996). Phylogenetic diversity of soda lake alkaliphiles. FEMS Microbiol. Ecol. 19, 181-191. ?doi: 10.1016/0168-6496(96)00003-7

Edbeib, M. F., Wahab, R. A., and Huyop, F. (2016). Halophiles: biology, adaptation, and their role in decontamination of hypersaline environments. World $\mathrm{J}$. Microbiol. Biotechnol. 32:135. doi: 10.1007/s11274-016-2081-9

Elshahawi, S. I., Shaaban, K. A., Kharel, M. K., and Thorson, J. S. (2015). A comprehensive review of glycosylated bacterial natural products. Chem. Soc. Rev. 44, 7591-7697. doi: 10.1039/c4cs00426d

Engel, A. S., Johnson, L. R., and Porter, M. L. (2013). Arsenite oxidase gene diversity among chloroflexi and proteobacteria from El tatio geyser field, Chile. FEMS Microbiol. Ecol. 83, 745-756. doi: 10.1111/1574-6941.12030

Escalante, G., Campos, V. L., Valenzuela, C., Yañez, J., Zaror, C., and Mondaca, M. A. (2009). Arsenic resistant bacteria isolated from arsenic contaminated river in the Atacama Desert (Chile). Bull. Environ. Contam. Toxicol. 83, 657-661. doi: 10.1007/s00128-009-9868-4

Escudero, L., Chong, G., Demergasso, C., Farías, M. E., Cabrol, N. A., Grin, E., et al. (2007). Investigating microbial diversity and UV radiation impact at the highaltitude Lake Aguas Calientes, Chile. Proc. SPIE Int. Soc. Opt. Eng. 6694:66940Z. doi: $10.1117 / 12.736970$

Farhangi-Abriz, S., and Nikpour-Rashidabad, N. (2017). Effect of lignite on alleviation of salt toxicity in soybean (Glycine max L.) plants. Plant Physiol. Biochem. 120, 186-193. doi: 10.1016/j.plaphy.2017.10.007

Farhangi-Abriz, S., and Torabian, S. (2017). Antioxidant enzyme and osmotic adjustment changes in bean seedlings as affected by biochar under salt stress. Ecotoxicol. Environ. Saf. 137, 64-70. doi: 10.1016/j.ecoenv.2016.11.029 
Feller, G., and Gerday, C. (2003). Psychrophilic enzymes: hot topics in cold adaptation. Nat. Rev. Microbiol. 1, 200-208. doi: 10.1038/nrmicro773

Fernandez-Turiel, J. L., Garcia-Valles, M., Gimeno-Torrente, D., SaavedraAlonso, J., and Martinez-Manent, S. (2005). The hot spring and geyser sinters of El Tatio, Northern Chile. Sediment. Geol. 180, 125-147. doi: 10.1016/j.sedgeo. 2005.07.005

Ferrario, C., Pittino, F., Tagliaferri, I., Gandolfi, I., Bestetti, G., Azzoni, R. S., et al. (2017). Bacteria contribute to pesticide degradation in cryoconite holes in an Alpine glacier. Environ. Pollut. 230, 919-926. doi: 10.1016/j.envpol.2017. 07.039

Finstad, K. M., Probst, A. J., Thomas, B. C., Andersen, G. L., Demergasso, C., Echeverría, A., et al. (2017). Microbial community structure and the persistence of cyanobacterial populations in salt crusts of the hyperarid Atacama Desert from genome-resolved Metagenomics. Front. Microbiol. 8:1435. doi: 10.3389/ fmicb.2017.01435

Flores, P. A., Amenábar, M. J., and Blamey, J. M. (2013). "Hot environments from Antarctica: source of thermophiles and hyperthermophiles, with potential biotechnological applications," in Thermophilic Microbes in Environmental and Industrial Biotechnology: Biotechnology of Thermophiles, eds T. Satyanarayana, J. Littlechild, and Y. Kawarabayasi. (Dordrecht: Springer), 99-118.

Fuentes, S., Barra, B., Caporaso, J. G., and Seeger, M. (2016). From rare to dominant: a fine-tuned soil bacterial bloom during petroleum hydrocarbon bioremediation. Appl. Environ. Microbiol. 82, 888-896. doi: 10.1128/AEM. 02625- 15

Fuentes, S., Méndez, V., Aguila, P., and Seeger, M. (2014). Bioremediation of petroleum hydrocarbons: catabolic genes, microbial communities and applications. Appl. Microbiol. Biotechnol. 98, 4781-4794. doi: 10.1007/s00253014-5684-9

Gabani, P., Prakash, D., and Singh, O. V. (2014). Bio-signature of ultravioletradiation-resistant extremophiles from elevated land. Am. J. Microbiol. Res. 2, 94-104. doi: 10.12691/ajmr-2-3-3

Gallardo, C., Monrás, J. P., Plaza, D. O., Collao, B., Saona, L. A., DuránToro, V., et al. (2014). Low-temperature biosynthesis of fluorescent semiconductor nanoparticles (CdS) by oxidative stress resistant Antarctic bacteria. J. Biotechnol. 187, 108-115. doi: 10.1016/j.jbiotec.2014.07.017

Galleguillos, P., Remonsellez, F., Galleguillos, F., Guiliani, N., Castillo, D., and Demergasso, C. (2008). Identification of differentially expressed genes in an industrial bioleaching heap processing low-grade copper sulphide ore elucidated by RNA arbitrarily primed polymerase chain reaction. Hydrometallurgy 94, 148-154. doi: 10.1016/j.hydromet.2008.05.031

García, M. T., Mellado, E., Ostos, J. C., and Ventosa, A. (2004). Halomonas organivorans sp. nov. a moderate halophile able to degrade oarmatic compound. Int. Syst. Evol. Microbiol. 54, 1723-1728. doi: 10.1099/ijs.0.63114-0

Gargarello, R. M., Di Gregorio, D., Huck, H., Fernandez Niello, J., and Curutchet, G. (2010). Reduction of uranium (VI) by Acidithiobacillus thiooxidans and Acidithiobacillus ferrooxidans. Hydrometallurgy 104, 529-532. doi: 10.1016/j.hydromet.2010.03.032

Gavrilescu, M. (2010). Environmental biotechnology: achievement, opportunities and challenges. Dyn. Biochem. Process. Biotechnol. Mol. Biol. 4, 1-36.

Gerdes, B., Brinkmeyer, R., Dieckmann, G., and Helmke, E. (2005). Influence of crude oil on changes of bacterial communities in Arctic sea-ice. FEMS Microbiol. Ecol. 53, 129-139. doi: 10.1016/j.femsec.2004.11.010

Ghosal, D., Omelchenko, M. V., Gaidamakova, E. K., Matrosova, V. Y., Vasilenko, A., Venkateswaran, A., et al. (2005). How radiation kills cells: survival of Deinococcus radiodurans and Shewanella oneidensis under oxidative stress. FEMS Microbiol. Rev. 29, 361-375. doi: 10.1016/j.femsre.2004. 12.007

Glennon, A., and Pfaff, R. M. (2003). The extraordinary thermal activity of the El Tatio geysers, Antofagasta Province, Chile. GOSA Trans. 8, 31-78.

Godin-Roulling, A., Schmidpeter, P. A., Schmid, F. X., and Feller, G. (2015). Functional adaptations of the bacterial chaperone trigger factor to extreme environmental temperatures. Environ. Microbiol. 17, 2407-2420. doi: 10.1111/ $1462-2920.12707$

Godoy-Faúndez, A., Antizar-Ladislao, B., Reyes-Bozo, L., Camano, A., and SáezNavarrete, C. (2008). Bioremediation of contaminated mixtures of desert mining soil and sawdust with fuel oil by aerated in-vessel composting in the Atacama Region (Chile). J. Hazard. Mater. 151, 649-657. doi: 10.1016/j. jhazmat.2007.06.038

Gonzalez-Aravena, M., Urtubia, R., Del Campo, K., Lavín, P., Wong, C. M. V., Cárdenas, C. A., et al. (2016). Antibiotic and metal resistance of cultivable bacteria in the Antarctic sea urchin. Antarct. Sci. 28, 261-268. doi: 10.1017/ S0954102016000109

González-Domenech, C. M., Béjar, V., Martínez-Checa, F., and Quesada, E. (2008). Halomonas nitroreducens sp.nov., a novel nitrate- and nitritereducing species. Int. J. Syst. Evol. Microbiol. 58, 872-876. doi: 10.1099/ijs.0. 65415-0

Gran-Scheuch, A., Fuentes, E., Bravo, D. M., Jiménez, J. C., and Pérez-Donoso, J. M. (2017). Isolation and characterization of phenanthrene degrading bacteria from diesel fuel-contaminated Antarctic soils. Front. Microbiol. 8:1634. doi: $10.3389 /$ fmicb.2017.01634

Grant, W. D. (2003). "Alkaline environments and biodiversity," in Extremophiles (Life Under Extreme External Conditions), ed. C. Gerday (Eolss: Oxford).

Grant, W. D. (2006). "Alkaline environments and biodiversity, in extremophilies," in Encyclopedia of Life Support Systems (EOLSS). Developed under the Auspices of the UNESCO, eds G. Charles and G. Nicolas (Eolss: Oxford).

Groth, I., Schumann, P., Rainey, F. A., Martin, K., Schuetze, B., and Augsten, K. (1997). Bogoriella caseilytica gen. nov., sp. nov., a new alkaliphilic actinomycete from a soda lake in Africa. Int. J. Syst. Bacteriol. 47, 788-794. doi: 10.1099/ 00207713-47-3-788

Guerra, M., González, K., González, C., Parra, B., and Martínez, M. (2015). Dormancy in Deinococcus sp. UDEC-P1 as a survival strategy to escape from deleterious effects of carbon starvation and temperature. Int. Microbiol. 18, 189-194. doi: 10.2436/20.1501.01.249

Gutiérrez, M. H., Galand, P. E., Moffat, C., and Pantoja, S. (2015). Melting glacier impacts community structure of bacteria, archea and fungi in a Chilean Patagonia fjord. Environ. Microbiol. 17, 3882-3897. doi: 10.1111/1462-2920. 12872

Hamamura, N., Olson, S. H., Ward, D. M., and Inskeeo, W. P. (2005). Diversity and functional analysis of bacterial communities associated with natural hydrocarbon seeps in acidic soils at Rainbow Springs, Yellowstone National Park. Appl. Environ. Microbiol. 71, 5943-5950. doi: 10.1128/AEM.71.10.59435950.2005

Hernández, M., Jia, Z., Conrad, R., and Seeger, M. (2011). Simazine application inhibits nitrification and changes the ammonia-oxidizing bacterial communities in a fertilized agricultural soil. FEMS Microbiol. Ecol. 78, 511-519. doi: 10.1111/j.1574-6941.2011.01180.x

Hernández, M., Morgante, V., Ávila, M., Villalobos, P., Miralles, P., González, M., and Seeger, M. (2008a). Novel s-triazine-degrading bacteria isolated from agricultural soils of central Chile for herbicide bioremediation. Electron. J. Biotechnol. 11, 1-7. doi: 10.2225/vol11-issue5-fulltext-4

Hernández, M., Villalobos, P., Morgante, V., González, M., Reiff, C., Moore E., and Seeger, M. (2008b). Isolation and characterization of a novel simazine-degrading bacterium from Chilean agricultural soils, Pseudomonas sp. MHP41. FEMS Microbiol. Lett. 286, 184-190. doi: 10.1111/j.1574-6968.2008. 01274.x

Hirsch, P., Gallikowski, C. A., Siebert, J., Peissl, K., Kroppenstedt, R., Schumann, P., et al. (2004). Deinococcus frigens sp. nov., Deinococcus saxicola sp. nov., and Deinococcus marmoris sp. nov., low temperature and draught-tolerating, UV-resistant bacteria from continental Antarctica. Syst. Appl. Microbiol. 27, 636-645. doi: 10.1078/0723202042370008

Horikoshi, K. (1999). Alkaliphiles: some applications of their products for biotechnology. Microbiol. Mol. Biol. Rev. 63, 735-750.

Hou, Y., Zhang, R., Yu, Z., Huang, L., Liu, Y., and Zhou, Z. (2017). Accelerated azo dye degradation and concurrent hydrogen production in the single-chamber photocatalytic microbial electrolysis cell. Bioresour. Technol. 224, 63-68. doi: 10.1016/j.biortech.2016.10.069

Houston, J., and Hartley, A. J. (2003). The central Andean west-slope rainshadow and its potential contribution to the origin of hyper-aridity in the Atacama Desert. Int. J. Climatol. 23, 1453-1464. doi: 10.1002/joc.938

Ilyas, S., Lee, J. C., and Kim, B. (2014). Bioremoval of heavy metals from recycling industry electronic waste by a consortium of moderate thermophiles: process development and optimization. J. Clean. Prod. 70, 194-202. doi: 10.1016/j. jclepro.2014.02.019 
Ivanova, A. E., Kizilova, A. K., Kanat'eva, A. Y., Kravchenko, I. K., Kurganov, A. A., and Belyaev, S. (2013). A hydrocarbon-oxidizing acidophilic thermotolerant bacterial association from sulfur blocks. Microbiology 82, 482-489. doi: 10.1134/ S0026261713040048

Johnson, D. B. (2008). Biodiversity and interactions of acidophiles: key to understanding and optimizing microbial processing of ores and concentrates. Trans. Nonferrous Met. Soc. China 18, 1367-1373. doi: 10.1016/S1003-6326(09) 60010-8

Johnson, D. B. (2007). "Physiology and ecology of acidophilic microorganisms,". in Physiology and Biochemistry of Extremophiles, eds G. Gerday and N. Glansdorff (Washington, DC: AMS press), 275-270. doi: 10.1128/9781555815 813.ch20

Jones, B., and Renaut, R. W. (1997). Formation of silica oncoids around geysers and hot springs at El Tatio, Northern Chile. Sedimentology 44, 287-304. doi: 10.1111/j.1365-3091.1997.tb01525.x

Karmanocky, F. J. III, and Benison, K. C. (2016). A fluid inclusion record of magmatic/hydrothermal pulses in acid Salar Ignorado gypsum, northern Chile. Geofluids 16, 490-506. doi: 10.1111/gfl.12171

Kataoka, M., Yamaoka, A., Kawasaki, K., Shigeri, Y., and Watanabe, K. (2014). Extraordinary denaturant tolerance of keratinolytic protease complex assemblies produced by Meiothermus ruber H328. Appl. Microbiol. Biotechnol. 98, 2973-2980. doi: 10.1007/s00253-0135155-8

Khalid, A., Kausar, F., Arshad, M., Mahmood, T., and Ahmed, I. (2012). Accelerated decolorization of reactive azo dyes under saline conditions by bacteria isolated from Arabian seawater sediment. Appl. Microbiol. Biotechnol. 96, 1599-1606. doi: 10.1007/s00253-012-3877-7

Kolmert, Å., and Johnson, D. B. (2001). Remediation of acidic waste waters using immobilised, acidophilic sulfate-reducing bacteria. J. Chem. Technol. Biotechnol. 76, 836-843. doi: 10.1002/jctb.453

Konhauser, K. O., Jones, B., Reysenbach, A. L., and Renaut, R. W. (2003). Hot spring sinters: keys to understanding Earth's earliest life forms. Can. J. Earth Sci. 40, 1713-1724. doi: 10.1139/e03-059

Kristiansen, E., and Zachariassen, K. E. (2005). The mechanism by which fish antifreeze proteins cause thermal hysteresis. Cryobiology 5, 262-280. doi: 10. 1016/j.cryobiol.2005.07.007

Krulwich, T. A. (1995). Alkaliphiles:'basic'molecular problems of $\mathrm{pH}$ tolerance and bioenergetics. Mol. Microbiol. 15, 403-410. doi: 10.1111/j.1365-2958.1995. tb02253.x

Krulwich, T. A., and Guffanti, A. A. (1989). Alkalophilic bacteria. Annu. Rev. Microbiol. 43, 435-463. doi: 10.1146/annurev.mi.43.100189.00 2251

Krulwich, T. A., Ito, M., Hicks, D. B., Gilmour, R., and Guffanti, A. A. (1998). pH homeostasis and ATP synthesis: studies of two processes that necessitate inward proton translocation in extremely alkaliphilic Bacillus species. Extremophiles 2, 217-222. doi: 10.1007/s007920050063

Kube, M., Chernikova, T. N., Al-Ramahi, Y., Beloqui, A., Lopez-Cortez, N., Guazzaroni, M. E., et al. (2013). Genome sequence and functional genomic analysisof the oil-degrading bacterium Oleispira antarctica. Nat. Commun. 4:2156. doi: $10.1038 /$ ncomms3156

Kulp, T. R., Han, S., Saltikov, C. W., Lanoil, B. D., Zargar, K., and Oremland, R. S. (2007). Effects of imposed salinity gradients on dissimilatory arsenate reduction, sulfate reduction, and other microbial processes in sediments from two California soda lakes. Appl. Environ. Microbiol. 73, 5130-5137. doi: 10. 1128/AEM.00771-07

Lamark, T., Kaasen, I., Eshoo, M. W., Falkenberg, P., McDougall, J., and Strom, A. R. (1991). DNA sequence and analysis of the bet genes enconding the osmoregulatory choline-glycine betaine pathway of Escherichia coli. Mol. Microbiol. 5, 1049-1064. doi: 10.1111/j.1365-2958.1991.tb0 1877.x

Lamilla, C., Braga, D., Castro, R., Guimarães, C., de Castilho, L. V., Freire, D. M., et al. (2018). Streptomyces luridus So3. 2 from Antarctic soil as a novel producer of compounds with bioemulsification potential. PLoS One 13:e0196054. doi: 10.1371/journal.pone.0196054

Landrum, J. T., Bennett, P. C., Engel, A. S., Alsina, M. A., Pastén, P. A., and Milliken, K. (2009). Partitioning geochemistry of arsenic and antimony, El Tatio Geyser Field, Chile. Appl. Geochem. 24, 664-676. doi: 10.1016/j.apgeochem. 2008.12.024
Lara, J., González, L. E., Ferrero, M., Díaz, G. C., Pedrós-Alió, C., and Demergasso, C. (2012). Enrichment of arsenic transforming and resistant heterotrophic bacteria from sediments of two salt lakes in Northern Chile. Extremophiles 16, 523-538. doi: 10.1007/s00792-012-0452-1

Lavin, P. L., Yong, S. T., Wong, C. M., and Gonzalez, A. R. (2017). The tradeoff between antimicrobial production and growth of an Antartic psychrotroph Streptomyces sp. strain INACH3013. Antarct. Sci. 29, 427-428. doi: 10.1017/ S0954102017000141

Lawson, C. E., and Lücker, S. (2018). Complete ammonia oxidation: an important control on nitrification in engineered ecosystems? Curr. Opin. Biotechnol. 50, 158-165. doi: 10.1016/j.copbio.2018.01.015

Lay, W. C. L., Liu, Y., and Fane, A. G. (2010). Impacts of salinity on the performance of high retention membrane bioreactors for water reclamation: a review. Water Res. 44, 21-40. doi: 10.1016/j.watres.2009.09.026

Le Borgne, S., Paniagua, D., and Vazquez-Duhalt, R. (2008). Biodegradation of organic pollutants by halophillic Bacteria and Archaea. J. Mol. Microbiol. Biotechnol. 15, 74-92. doi: 10.1159/000121323

Lebre, P. H., De Maayer, P., and Cowan, D. A. (2017). Xerotolerant bacteria: surviving through a dry spell. Nat. Rev. Microbiol. 15, 285-296. doi: 10.1038/ nrmicro.2017.16

Leigh, M. B., Wu, W. M., Cardenas, E., Uhlik, O., Carroll, S., Gentry, T., et al. (2015). Microbial communities biostimulated by ethanol during uranium (VI) bioremediation in contaminated sediment as shown by stable isotope probing. Front. Environ. Sci. Eng. 9, 453-464. doi: 10.1007/s11783-014-0721-6

Li, S. J., Hua, Z. S., Huang, L. N., Li, J., Shi, S. H., and Chen, L. X., et al. (2014). Microbial communities evolve faster in extreme environments. Sci. Rep. 27:6205. doi: 10.1038/srep06205

Liu, H. L., Chen, B. Y., Lan, Y. W., and Cheng, Y. C. (2004). Biosorption of Zn (II) and $\mathrm{Cu}$ (II) by the indigenous Thiobacillus thiooxidans. Chem. Eng. J. 97, 195-201. doi: 10.1016/S1385-8947(03)00210-9

Liu, Z., Cichocki, N., Bonk, F., Günther, S., Schattenberg, F., Harms, H., Müller, S. (2018). Ecological stability properties of microbial communities assessed by flow cytometry. $m$ Sphere 3:e00564-17. doi: 10.1128/mSphere.00564- 17

Loperena, L., Soria, V., Varela, H., Lupo, S., Bergalli, A., Guigou, M., et al. (2012). Extracellular enzymes produced by microorganisms isolated from maritime Antarctica. World J. Microbiol. Biotechnol. 28, 2249-2256. doi: 10.1007/s11274012-1032-3

López, L., Pozo, C., Rodelas, B., Calvo, C., Juárez, B., Martínez-Toledo, M. V., et al. (2005). Identification of bacteria isolated from an oligotrophic lake with pesticide removal capacities. Ecotoxicology 14, 299-312. doi: 10.1007/s10646003-6367-y

Mackenzie, R., Pedros-Alio, C., and Díez, B. (2013). Bacterial composition of microbial mats in hot springs in Northern Patagonia: variations with seasons and temperature. Extremophiles 17, 123-136. doi: 10.1007/s00792-018-1027-6

Madigan, M. T., Martinko, J. M., and Parker, J. (2000). Brock Biology of Microorganisms. New Jersey, NJ: Prentice Hall.

Maier, J., Kandelbauer, A., Erlacher, A., Cavaco-Paulo, A., and Gübitz, G. M. (2004). A new alkali-thermostable azoreductase from Bacillus sp. strain SF. Appl. Environ. Microbiol. 70, 837-844. doi: 10.1128/AEM.70.2.837-844.2004

Mandakovic, D., Cabrera, P., Pulgar, R., Maldonado, J., Aravena, P., Latorre, M., et al. (2015). Complete genome sequence of Microbacterium sp. CGR1, bacterium tolerant to wide abiotic conditions isolated from the Atacama Desert. J. Biotechnol. 216, 149-150. doi: 10.1016/j.jbiotec.2015.10.020

Mandakovic, D., Maldonado, J., Pulgar, R., Carrera, P., Gaete, A., Urtuvia, V., et al. (2018). Microbiome analysis and bacterial isolation from Lejía Lake soil in Atacama Desert. Extremophiles 22, 665-673. doi: 10.1007/s00792-018-1027-6

Mangano, S., Michaud, L., Caruso, C., and Lo Giudice, A. (2013). Metal and antibiotic resistance in psychrotrophic bacteria associated with the Antarctic sponge Hemigellius pilosus (Kirkpatrick, 1907). Polar Biol. 37, 227-235. doi: 10.1007/s00300-013-1426-1

Margesin, R., and Schinner, F. (2001). Bioremediation (natural attenuation and biostimulation) of diesel-oil-contaminated soil in an alpine glacier skiing area. Appl. Environ. Microbiol. 67, 3127-3133. doi: 10.1128/AEM.67.7.3127-3133. 2001

Marizcurrena, J. J., Morel, M. A., Braña, V., Morales, D., Martinez-López, W., and Castro-Sowinski, S. (2017). Searching for novel photolyases in UVC-resistant Antarctic bacteria. Extremophiles 21, 409-418. doi: 10.1007/s00792-0160914-y 
Matsuno, T., and Yumoto, I. (2015). Bioenergetics and the role of soluble cytochromes $\mathrm{c}$ for alkaline adaptation in gram-negative alkaliphilic Pseudomonas. Biomed. Res. Int. 2015:847945. doi: 10.1155/2015/847945

Mattimore, V., and Battista, J. R. (1996). Radioresistance of Deinococcus radiodurans: functions necessary to survive ionizing radiation are also necessary to survive prolonged desiccation. J. Bacteriol. 178, 633-637. doi: 10.1128/jb.178. 3.633-637.1996

Matzke, J., Schwermann, B., and Bakker, E. P. (1997). Acidostable and acidophilic proteins: the example of the $\alpha$-amylase from Alicyclobacillus acidocaldarius. Comp. Biochem. Physiol. 118, 475-479. doi: 10.1016/S0300-9629(97)00008-X

Méndez, V., Fuentes, S., Morgante, V., Hernández, M., González, M., Moore, E., et al. (2017). Novel hydrocarbon-degrading and heavy metal-resistant Acinetobacter, Kocuria and Pseudomonas strains isolated from a crude oilpolluted soil in central Chile. J. Soil Sci. Plant Nutr. 17, 1074-1087. doi: 10.4067/ S0718-95162017000400017

Michels, M., and Bakker, E. P. (1985). Generation of a large, protonophoresensitive proton motive force and $\mathrm{pH}$ difference in the acidophilic bacteria Thermoplsma acidophilum and Bacillus acidocaldarius. J. Bacteriol. 161, 231-237.

Miller, S. R. (2007). "Diversity of the cosmopolitan thermophile Mastigocladus laminosus at global, regional and local scales", in Algae and Cyanibacteria in Extreme Environments. Cellular Origin, Life in Extreme Habitats and Astrobiology, ed. J. Seckbach (Dordrecht: Springer), 399-410. doi: 10.1007/9781-4020-6112-7_21

Mnif, S., Sayadi, S., and Chamkha, M. (2014). Biodegradative potential and characterization of a novel aromatic-degrading bacterium isolated from a geothermal oil field under saline and thermophilic conditions. Int. Biodeterior. Biodegradation 86, 258-264. doi: 10.1016/j.ibiod.2013.09.015

Mohammadipanah, F., and Wink, J. (2016). Actinobacteria from arid and desert habitats: diversity and biological activity. Front. Microbiol. 6:1541. doi: 10.3389/ fmicb.2015.01541

Montero-Silva, F., Durán, N., and Seeger, M. (2018). Synthesis of extracellular gold nanoparticles using Cupriavidus metallidurans $\mathrm{CH} 34$ cells. IET Nanobiotechnol. 12, 40-46. doi: 10.1049/iet-nbt.2017.0185

Moreno, M. L., Piubeli, F., Bonfá, M. R., García, M. T. L., Durrant, L. R., and Mellado, E. (2012). Analysis and characterization of cultivable extremophilic hydrolytic bacterial community in heavy-metal-contaminated soils from the atacama desert and their biotechnological potentials. J. Appl. Microbiol. 113, 550-559. doi: 10.1111/j.1365-2672.2012.05366.x

Morgante, V., López-López, A., Flores, C., González, M., González, B., Vásquez, M., et al. (2010). Bioaugmentation with Pseudomonas sp. strain MHP41 promotes simazine attenuation and bacterial community changes in agricultural soils. FEMS Microbiol. Ecol. 71, 114-126. doi: 10.1111/j.1574-6941.2009.00790.x

Morita, R. Y. (1975). Psychrophilic bacteria. Bacteriol. Rev. 39, 144-167.

Mrazek, J. (2002). New technology may reveal mechanisms of radiation resistance in Deinococcus radiodurans. Proc. Natl. Acad. Sci. U.S.A. 99, 10943-10944. doi: 10.1073/pnas.182429699

Mukherjee, S., Mishra, A., and Trenberth, K. E. (2018). Climate change and drought: a perspective on drought indices. Curr. Clim. Change Rep. 4, 145-163. doi: 10.1007/s40641-018-0098-x

Muñoz, N., and Charrier, R. (1996). Uplift of the western border of the Altiplano on west-vergent thrust system, Northern Chile. J. South Am. Earth Sci. 9, 171-181. doi: 10.1016/0895-9811(96)00004-1

Muñoz, P. A., Flores, P. A., Boehmwald, F. A., and Blamey, J. M. (2011). Thermophilic bacteria present in a sample from Fumarole Bay, Deception Island. Antarct. Sci. 23, 549-555. doi: 10.1017/S0954102011000393

Muñoz, P. A., Márquez, S. L., González-Nilo, F. D., Márquez-Miranda, V., and Blamey, J. M. (2017). Structure and application of antifreeze proteins from Antarctic bacteria. Microb. Cell Fact. 16:138. doi: 10.1186/s12934-017-0737-2

Nakayama, T., Tsuruoka, N., Akai, M., and Nishino, T. (2000). Thermostable collagenolytic activity of a novel thermophilic isolate, Bacillus sp. strain NTAP1. J. Biosci. Bioeng. 89, 612-614. doi: 10.1016/S1389-1723(00)80067-5

Natarajan, K. A. (2008). Microbial aspects of acid mine drainage and its bioremediation. Trans. Nonferrous Met. Soc. China 18, 1352-1360. doi: 10.1016/ S1003-6326(09)60008-X

Navarro-González, R., Rainey, F. A., Molina, P., Bagaley, D. R., Hollen, B. J., de la Rosa, J., et al. (2003). Mars-like soils in the Atacama Desert, Chile, and the dry limit of microbial life. Science 302, 1018-1021. doi: 10.1126/science.1089143
Ni, G., Christel, S., Roman, P., Wong, Z. L., Bijmans, M. F., and Dopson, M. (2016). Electricity generation from an inorganic sulfur compound containing mining wastewater by acidophilic microorganisms. Res. Microbiol. 167, 568-575. doi: 10.1016/j.resmic.2016.04.010

Okibe, N., Gericke, M., Hallberg, K. B., and Johnson, D. B. (2003). Enumeration and characterization of acidophilic microorganisms isolated from a pilot plant stirred-tank bioleaching operation. Appl. Environ. Microbiol. 69, 1936-1943. doi: 10.1128/AEM.69.4.1936-1943.2003

Órdenes-Aenishanslins, N., Anziani-Ostuni, G., Vargas-Reyes, M., Alarcón, J., Tello, A., and Pérez-Donoso, J. M. (2016). Pigments from UV-resistant Antarctic bacteria as photosensitizers in dye sensitized solar cells. J. Photochem. Photobiol. B 162, 707-714. doi: 10.1016/j.jphotobiol.2016.08.004

Ordoñez, O., Lanzarotti, E., Kurth, D., Cortez, N., Farias, M. E., and Turjanski, A. G. (2015). Genome comparison of two Exiguobacterium strains from high altitude Andean lakes with different arsenic resistance: identification and 3D modeling of the Acr3 efflux pump. Front. Environ. Sci. 3:50. doi: 10.3389/fenvs. 2015.00050

Oremland, R. S., Stolz, J. F., and Hollibaugh, J. T. (2004). The microbial arsenic cycle in Mono Lake, California. FEMS Microbiol. Ecol. 48, 15-27. doi: 10.1016/ j.femsec.2003.12.016

Oren, A. (1999). Bioenergetic aspects of halophilism. Microbiol. Mol. Biol. Rev. 63, 334-348. doi: 10.1016/j.jphotobiol.2016.08.004

Oren, A. (2002). Diversity of halophilic microorganisms: Environments, phylogeny, physiology, and applications. J. Ind. Microbiol. Biotechnol. 28, 56-63. doi: $10.1038 / \mathrm{sj} / \mathrm{jim} / 7000176$

Oren, A., Gurevich, P., Azachi, M., and Henis, Y. (1992). Microbial degradation of pollutants at high salt concentrations. Biodegradation 3, 387-398. doi: 10.1007/ BF00129095

Oukarroum, A., Bussotti, F., Goltsev, V., and Kalaji, H. M. (2015). Correlation between reactive oxygen species production and photochemistry of photosystem I and II in Lemna gibba L. plants uder salt stress. Environ. Exp. Bot. 109, 80-88. doi: 10.1016/j.envexpbot.2014.08.005

Panda, S., Mishra, S., and Akcil, A. (2016). Bioremediation of acidic mine effluents and the role of sulfidogenic biosystems: a mini-review. Euro Mediterr. J. Environ. Integr. 1:8. doi: 10.1007/s41207-016-0008-3

Paulino-Lima, I. G., Fujishima, K., Navarrete, J. U., Galante, D., Rodrigues, F., Azua-Bustos, A., et al. (2016). Extremely high UV-C radiation resistant microorganisms from desert environments with different manganese concentrations. J. Photochem. Photobiol. B Biol. 163, 327-336. doi: 10.1016/j.jphotobiol.2016.08.017

Pérez, V., Hengst, M., Kurte, L., Dorador, C., Jeffrey, W. H., Wattiez, R., et al. (2017). Bacterial survival under extreme UV radiation: a comparative proteomics study of Rhodobacter sp., isolated from high altitude wetlands in Chile. Front. Microbiol. 8:1173. doi: 10.3389/fmicb.2017.01173

Pikuta, E. V., Hoover, R. B., and Tang, J. (2007). Microbial extremophilesat the limits of life. Crit. Rev. Microbiol. 33, 183-209. doi: 10.1080/ 10408410701451948

Piubeli, F., Moreno, M., Kishi, T. L., Henrique-Silva, F., García, M. T., and Mellado, E. (2015). Phylogenetic profiling and diversity of bacterial communities in the Death Valley, an extreme habitat in the Atacama Desert. Indian J. Microbiol. 55, 392-399. doi: 10.1016/j.syapm.2010.02.007

Plenge, M. F., Engel, A. S., Omelon, C. R., and Bennett, P. (2017). Thermophilic archaeal diversity and methanogenesis from El Tatio geyser field, Chile. Geomicrobiol. J. 34, 220-230. doi: 10.1080/01490451.2016.1168496

Plominsky, A., Delherbe, N., Ugalde, J., Allen, E., Blanchet, M., Keda, P., et al. (2014). Metagenome sequencing of the microbial community of a solar saltern crystallizer pond at Cáhuil Lagoon, Chile. Genome Announc. 2:e01172-14. doi: 10.1128/genomeA.01172-14

Poland, J. S., Riddle, M. J., and Zeeb, B. A. (2003). Contaminants in the arctic and the antarctic: a comparison of sources, impacts, and remediation options. Polar Rec. 39, 369-383. doi: 10.1017/S0032247403002985

Prasad, A. S., and Rao, K. V. (2013). Aerobic biodegradation of Azo dye by Bacillus cohnii MTCC 3616; an obligately alkaliphilic bacterium and toxicity evaluation of metabolites by different bioassay systems. Appl. Microbiol. Biotechnol. 97, 7469-7481. doi: 10.1007/s00253-012-4492-3

Procesi, M. (2014). Geothermal potential evaluation for Northern Chile and suggestions for new energy plans. Energies 7, 5444-5459. doi: 10.3390/ en7085444 
Quatrini, R., Escudero, L. V., Moya-Beltrán, A., Galleguillos, P. A., Issottaa, F., Acosta, M., et al. (2017). Draft genome sequence of Acidithiobacillus thiooxidans CLST isolated from the acidic hypersaline Gorbea salt flat in northern Chile. Stand. Genomic Sci. 12:84. doi: 10.1186/s40793-017-0305-8

Quiroz, M., Triadó-Margarit, X., Casamayor, E. O., and Gajardo, G. (2015). Comparison of the Artemia bacteria associations in brines, laboratory cultures and the gut environment: a study based on Chilean hypersaline environments. Extremophiles 19, 135-147. doi: 10.1007/s00792-014-0694-1

Rafferty, J. P. (2010). Plate Tectonics, Volcanoes, and Earthquakes. New York, NY: Britannica Educational Publishing.

Rahman, K. S., Rahman, T. J., Kourkoutas, Y., Petsas, I., Marchatn, R., and Banat, I. M. (2003). Enhanced bioremediation of n-alkane in petroleum sludge using bacterial consortium amended with rhamnolipid and micronutirents. Bioresour. Technol. 90, 159-168. doi: 10.1016/S0960-8524(03) 00114-7

Rainey, F. A., Ferreira, M., Nobre, M. F., Ray, K., Bagaley, D., Earl, A. M., et al. (2007). Deinococcus peraridilitoris sp. nov., isolated from a coastal desert. Int. J. Syst. Evol. Microbiol. 57, 1408-1412. doi: 10.1099/ijs.0.64956-0

Rainey, F. A., Ray, K., Ferreira, M., Gatz, B. Z., Nobre, F., and Bagaley, D., et al. (2005). Extensive diversity of ionizing-radiation-resistant bacteria recovered from Sonoran Desert soil and description of nine new species of the genus Deinococcus obtained from a single soil sample. Appl. Environ. Microbiol. 71, 5225-5235. doi: 10.1128/AEM.71.11.7630.2005

Rampelotto, P. H. (2013). Extremophiles and extreme environtments. Life 3, 482-485. doi: 10.3390/life3030482

Rastogi, G., Bhalla, A., Adhikari, A., Bischoff, K. M., Hughes, S. R., Christopher, L. P., et al. (2010). Characterization of thermostable cellulases produced by Bacillus and Geobacillus strains. Bioresour. Technol. 101, 8798-8806. doi: 10. 1016/j.biortech.2010.06.001

Remonsellez, F., Galleguillos, F., Moreno-Paz, M., Parro, V., Acosta, M., and Demergasso, C. (2009). Dynamic of active microorganisms inhabiting a bioleaching industrial heap of low-grade copper sulfide ore monitored by real-time PCR and oligonucleotide prokaryotic acidophile microarray. Microb. Biotechnol. 2, 613-624. doi: 10.1111/j.1751-7915.2009.00 112.x

Riddle, M. R., Baxter, B. K., and Avery, B. J. (2013). Molecular identification of microorganisms associated with the brine shrimp Artemia franciscana. Aquat. Biosyst. 9:7. doi: 10.1186/2046-9063-9-7

Rigoldi, F., Donini, S., Redaelli, A., Parisini, E., and Gautieri, A. (2018). Review: engineering of thermostable enzymes for industrial applications. APL Bioeng. 2:011501. doi: 10.1063/1.4997367

Risacher, F., Alonso, H., and Salazar, C. (2003). The origin of brines and salts in Chilean salars: a hydrochemical review. Earth Sci. Rev. 63, 249-293. doi: 10.1016/S0012-8252(03)00037-0

Risacher, F., and Fritz, B. (2009). Origin of salts and brine evolution of Bolivian and Chilean salars. Aquat. Geochem. 15, 123-157. doi: 10.1007/s10498-0089056-x

Robinson, C. K., Wierzchos, J., Black, C., Crits-Christoph, A., Ma, B., Ravel, J., et al. (2015). Microbial diversity and the presence of algae in halite endolithic communities are correlated to atmospheric moisture in the hyper-arid zone of the Atacama Desert. Environ. Microbiol. 17, 299-315. doi: 10.1111/1462-2920. 12364

Rodriguez-Rojas, F., Castro-Nallar, E., Undabarrena, A., Muñoz-Díaz, P., ArenasSalinas, M., Díaz-Vásquez, W. et al. (2016a). Draft genome sequence of a multi-metal resistance bacterium Pseudomonas putida ATH-43 isolated from Greenwich Island, Antarctica. Front. Microbiol. 7:1777. doi: 10.3389/fmicb. 2016.01777

Rodriguez-Rojas, F., Diaz-Vasquez, W., Undabarrena, A., Muñoz-Diaz, P., Arenas, F., and Vásquez, C. (2016b). Mercury-mediated cross-resistance to tellurite in Pseudomonas spp. isolated from the Chilean Antarctic territory. Metallomics 8, 108-117. doi: 10.1039/c5mt00256g

Rohban, R., Amoozegar, M. A., and Ventosa, A. (2009). Screening and isolation of halophilic bacteria producing extracellular hydrolyses from Howz Soltan Lake, Iran. J. Ind. Microbiol. Biotechnol. 36, 333-340. doi: 10.1007/s10295-0080500-0

Rojas, L. A., Yañez, C., González, M., Lobos, S., Smalla, K., and Seeger, M. (2011). Characterization of the metabolically modified heavy metalresistant Cupriavidus metallidurans strain MSR33 generated for mercury bioremediation. PLoS One 6:e17555. doi: 10.1371/journal.pone.001 7555

Romano, I., Lama, L., Nicolaus, B., Poli, A., Gambacorta, A., and Giordano, A. (2006). Halomonas alkiliphila sp. nov., a novel halotolerant alkalphilic bacterium isolated from a salt pool in Campania (Italy). J. Gen. Appl. Microbiol. 52, 339-348. doi: 10.1016/j.syapm.2005.03.010

Romero-González, M., Nwaobi, B. C., Hufton, J. M., and Gilmour, D. J. (2016). Ex-situ bioremediation of U (VI) from contaminated mine water using Acidithiobacillus ferrooxidans strains. Front. Environ. Sci. 4:39. doi: 10.3389/ fenvs.2016.00039

Rowe, J. J., Fournier, R. O., and Morey, G. W. (1973). Chemical analysis of thermal waters in Yellowstone National Park, Wyoming, 1960-65. U.S. Geol. Surv. Bull. 1303:31.

Saavedra, M., Acevedo, F., González, M., and Seeger, M. (2010). Mineralization of PCBs by the genetically modified strain Cupriavidus necator JMS34 and its application for bioremediation of PCBs in soil. Appl. Microbiol. Biotechnol. 87, 1543-1554. doi: 10.1007/s00253-010-2575-6

Sachdev, D. P., and Cameotra, S. S. (2013). Biosurfactants in agriculture. Appl. Microbiol. Biotechnol. 97, 1005-1016. doi: 10.1007/s00253-012-4641-8

Santhanam, R., Rong, X., Huang, Y., Andrews, B. A., Asenjo, J. A., and Goodfellow, M. (2013). Streptomyces bullii sp. nov., isolated from a hyperarid Atacama Desert soil. Antonie Van Leeuwenhoek 103:367-373. doi: 10.1007/ s10482-012-9816-X

Sar, P., Kazy, S. K., Paul, D., and Sarkar, A. (2013). "Metal bioremediation by thermophilic microorganisms," in Thermophilic Microbes in Environmental and Industrial Biotechnology: Biotechnology of Thermophiles, eds T. Satyanarayana, J. Littlechild, and Y. Kawarabayasi (Dordrecht: Springer), 171-201. doi: 10.1007/ 978-94-007-5899-5_6

Scherson, R. A., Thornhill, A. H., Urbina-Casanova, R., Freyman, W. A., Pliscoff, P. A., and Mishler, B. D. (2017). Spatial phylogenetics of the vascular flora of Chile. Mol. Phylogenet. Evol. 112, 88-95. doi: 10.1016/j.ympev.2017.04.021

Scott, S., Dorador, C., Oyanedel, J. P., Tobar, I., Hengst, M., Maya, G., et al. (2015). Microbial diversity and trophic components of two high altitude wetlands of the Chilean Altiplano. Gayana 79, 45-56. doi: 10.4067/S0717-65382015000100006

Seeger, M., and Jerez, C. A. (1993). Response of Thiobacillus ferrooxidans to phosphate limitation. FEMS Microbiol. Rev. 11:42. doi: 10.1111/j.1574-6976. 1993.tb00264.x

Seeger, M., Osorio, G., and Jerez, C. A. (1996). Phosphorylation of GroEL and DnaK and other proteins from Thiobacillus ferrooxidans grown under different conditions. FEMS Microbiol. Lett. 138, 129-134. doi: 10.1111/j.1574-6968.1996. tb08145.x

Sekhon Randhawa, K. K., and Rahman, P. K. (2014). Rhamnolipid biosurfactantspast, present, and future scenario of global market. Front. Microbiol. 5:454. doi: $10.3389 /$ fmicb.2014.00454

Serour, E., and Antranikian, G. (2002). Novel thermoactive glucoamylases from the thermoacidophilic Archaea Thermoplasma acidophilum, Picrophilus torridus and Picrophilus oshimae. Antonie Van Leeuwenhoek 81, 73-83. doi: 10.1023/A: 1020525525490

Sharma, A., Kawarabayasi, Y., and Satyanarayana, T. (2012). Acidophilic bacteria and archaea: acid stable biocatalysts and their potential applications. Extremophiles 16, 1-19. doi: 10.1007/s00792-011-0402-3

Sharma, A., Parashar, D., and Satyanarayana, T. (2016). "Acidophilic microbes: biology and applications," in Biotechnology of Extremophiles: Advances and Challenges, ed. P.H. Rampelotto (Porto Alegre: Springer), 215-241.

Sheela, B., Khasim, S., and Rao, O. (2014). Bioremediation of ammonia using ammonia oxidizing bacteria isolated from Sewage. Int. J. Environ. Bioremediat. Biodegrad. 2, 146-150. doi: 10.12691/ijebb-2-4-1

Siddikee, M. A., Chauhan, P. S., Anandham, R., Han, G. H., and Sa, T. (2010). Isolation, characterization, and use for plant growth promotion under salt stress, of ACC deaminase-producing halotolerant bacteria derived from coastal soil. J. Microbiol. Biotechnol. 20, 1577-1584. doi: 10.4014/jmb.1007.07011

Siddiqui, K. S., Williams, T. J., Wilkins, D., Yau, S., Allen, M., Brown, M., et al. (2013). Psychrophiles. Annu. Rev. Earth Planet. Sci. 41, 87-115. doi: 10.1146/ annurev-earth-040610-133514

Smedley, P. L., and Kinniburgh, D. G. (2002). A review of the source, behaviour and distribution of arsenic in natural waters. Appl. Geochem. 17, 517-568. doi: 10.1016/S0883-2927(02)00018-5 
Solari, M. A., Herve, F., and Martinez, J. (2004). The presence of living stromatolites at Laguna Amarga, Torres del Paine National Park, southernmost Chile. Abstr. Prog. Geol. Soc. Am. 36:57.

Sorokin, D. Y., Zhilina, T. N., Lysenko, A. M., Tourova, T. P., and Spiridonova, E. M. (2006). Metabolic versatility of haloalkaliphilic bacteria from soda lakes belonging to the Alkalispirillum-Alkalilimnicola group. Extremophiles 10, 213-220. doi: 10.1007/s00792-005-0487-7

Soto, P., Acosta, M., Tapia, P., Contador, Y., Velásquez, A., Espoz, C., et al. (2013). From mesophilic to moderate thermophilic populations in an industrial heap bioleaching process. Adv. Mat. Res. 825, 376-379.

Squeo, F., Warner, B. R., Aravena, D., and Espinoza, D. (2006). Bofedales: high altitude peatlands of the central Andes. Rev. Chil. Hist. Nat. 79, 245-255. doi: 10.4067/S0716-078X2006000200010

Stapleton, R. D., Savage, D. C., Sayler, G. S., and Stacey, G. (1998). Biodegradation of aromatic hydrocarbons in an extremely acidic environment. Appl. Environ. Microbiol. 64, 4180-4184.

Sulonen, M. L., Kokko, M. E., Lakaniemi, A. M., and Puhakka, J. A. (2015). Electricity generation from tetrathionate in microbial fuel cells by acidophiles. J. Hazard. Mater. 284, 182-189. doi: 10.1016/j.jhazmat.2014.10.045

Suzuki, Y., Kelly, S. D., Kemner, K. M., and Banfield, J. F. (2003). Microbial populations stimulated for hexavalent uranium reduction in uranium mine sediment. Appl. Environ. Microbiol. 69, 1337-1346. doi: 10.1128/AEM.69.3. 1337-1346.2003

Takeuchi, F., and Sugio, T. (2006). Volatilization and recovery of mercury from mercury-polluted soils and wastewaters using mercury-resistant Acidithiobacillus ferrooxidans strains SUG 2-2 and MON-1. Environ. Sci. 13, 305-316.

Tang, K. H., Barry, K., Dalin, E., Han, C. S., Hauser, L. J., Honchak, B. M., et al. (2011). Complete genome sequence of the filamentous anoxygenic phototrophic bacterium Chloroflexus aurantiacus. BMC Genomics 12:334. doi: 10.1186/1471-2164-12-334

Tassi, F., Aguilera, F., Darrah, T., Vaselli, O., Capaccioni, B., and Poreda, R. J. (2010). Fluid geochemistry of hydrothermal system in the Arica-Parinacota, Tarapacá and Antofagasta regions (northern Chile). J. Volcanol. Geotherm. Res. 192, 1-15. doi: 10.1016/j.volgeores.2010.02.006

Tomova, I., Stoilova-Disheva, M., Lazarkevich, I., and Vasileva-Tonkova, E. (2015). Antimicrobial activity and resistance to heavy metals and antibiotics of heterotrophic bacteria isolated from sediment and soil samples collected from two Antarctic islands. Front. Life Sci. 8, 348-357. doi: 10.1080/21553769.2015. 104413

Undabarrena, A., Beltrametti, F., Claverías, F. P., González, M., Moore, E. R. B., Seeger, M., et al. (2016). Exploring the diversity and antimicrobial potential of marine actinobacteria from the Comau Fjord in Northern Patagonia, Chile. Front. Microbiol. 7:1135. doi: 10.3389/fmicb.2016.01135

Undabarrena, A., Ugalde, J. A., Seeger, M., and Cámara, B. (2017). Genomic data mining of the marine actinobacteria Streptomyces sp. H-KF8 unveils insights into multi-stress related genes and metabolic pathways involved in antimicrobial synthesis. PeerJ 5:e2912. doi: 10.7717/peerj.2912

Urbieta, M. S., Donati, E. R., Chan, K. G., Sin, L. L., and Goh, K. M. (2015a). Thermophiles in the genomic era: biodiversity, science, and applications. Biotechnol. Adv. 33, 633-647. doi: 10.1016/j.biotechadv.2015.04.007

Urbieta, M. S., Gonzalez-Toril, E., Bazán, A. A., Giaveno, M. A., and Donati, E. (2015b). Comparison of the microbial communities of hot springs waters and the microbial biofilms in the acidic geothermal area of Copahue (Neuquen, Argentina). Extremophiles 19, 437-450. doi: 10.1007/s00792-015-0729-2

Vacheron, J., Desbrosses, G., Bouffaud, M. L., Touraine, B., Moënne-Loccoz, Y., Muller, D., et al. (2013). Plant growth-promoting rhizobacteria and root system functioning. Front. Plant Sci. 4:356. doi: 10.3389/fpls.2013.00356

Valdebenito-Rolack, E., Ruiz-Tagle, N., Abarzúa, L., Aroca, G., and Urrutia, H. (2017). Characterization of a hyperthermophilic sulphur-oxidizing biofilm produced by archaea isolated from a hot spring. Electron. J. Biotechnol. 25, 58-63. doi: 10.1016/j.ejbt.2016.11.005

Valipour, M. (2014). Drainage, waterlogging, and salinity. Arch. Agron. Soil Sci. 60, 1625-1640. doi: 10.1080/03650340.2014.905676

van Beilen, J. B., and Funhoff, E. G. (2007). Alkane hydroxylases involved in microbial alkane degradation. Appl. Microbiol. Biotechnol. 74, 13-21. doi: 10. 1007/s00253-006-0748-0
Vasquez-Ponce, F., Higuera-Llantén, S., Pavlov, M. S., Ramirez-Orellana, R., Marshall, S. H., and Olivares-Pacheco, J. (2017). Alginate overproduction and biofilm formation by psychrotolerant Pseudomonas mandelii dependent on temperatura in Antartic marine sediments. Electronic J. Biotechnol. 28, 27-34. doi: 10.1016/j.ejbt.2017.05.001

Vázquez, S., Monien, P., Minetti, R. P., Jürgens, J., Curtosi, A., Primitz, V. J., et al. (2017). Bacterial communities and chemical parameters in soils and coastal sediments in response to diesel spills at Carlini Station, Antarctica. Sci. Total Environ. 605-606, 26-37. doi: 10.1016/j.scitotenv.2017.06.129

Vieille, C., and Zeikus, J. G. (1996). Thermozymes: identifying molecular determinants of protein structural and functional stability. Trends Biotechnol. 14, 183-190. doi: 10.1016/0167-7799(96)10026-3

Villagrán, C., and Armesto, J. J. (2005). "Fitogeografía histórica de la cordilera de la costa de chile", in Historia, biogeografía y ecología de los bosques costeros de Chile, eds C. Smith-Ramírez, J. J. Armesto, and C. Valdovinos (Santiago: Editorial Universitaria), 99-115.

Villagrán, C., and Hinojosa, F. (1997). Historia de los bosques del sur de sudamérica, II: análisis fitogeográfico. Rev. Chil. Hist. Nat. 70, 241-267.

Wang, L., Cheng, G., Dai, Z., Zhao, Z. S., Liu, F., Li, S., et al. (2015). Degradation of intact chicken feathers by Thermoactinomyces sp. CDF and characterization of its keratinolytic protease. Appl. Microbiol. Biotechnol. 99, 3949-3959. doi: $10.1007 / \mathrm{s} 00253-014-6207-4$

Warren, J. K. (2010). Evaporites through time: tectonic, climatic and eustatic controls in marine and nonmarine deposits. Earth Sci. Rev. 98, 217-268. doi: 10.1016/j.earscirev.2009.11.004

Warren-Rhodes, K. A., Rhodes, K. L., Pointing, S. B., Ewing, S. A., Lacap, D. C., Gómez-Silva, B., et al. (2006). Hypolithic Cyanobacteria, dry limit of photosynthesis, and microbial ecology in the hyperarid Atacama Desert. Microb. Ecol. 52, 389-398. doi: 10.1007/s00248-006-9055-7

Weiss, M. C., Sousa, F. L., Mrnjavac, N., Neukirchen, S., Roettger, M., NelsonSathi, S., et al. (2016). The physiology and habitat of the last universal common ancestor. Nat. Microbiol. 1:16116. doi: 10.1038/nmicrobiol.2016.116

Woese, C. R., Kandler, O., and Wheelis, M. L. (1990). Towards a natural system of organisms: proposal for the domains archaea, bacteria, and eucarya. Proc. Natl. Acad. Sci. U.S.A. 87, 4576-4579. doi: 10.1073/pnas.87.12.4576

Xu, L., Wu, Y. H., Zhou, P., Cheng, H., Liu, Q., and Xu, X. W. (2018). Investigation of the thermophilic mechanism in the genus Porphyrobacter by comparative genomic analysis. BMC Genomics 19:385. doi: 10.1186/s12864-0184789-4

Yakimov, M. M., Giuliano, L., Chernikova, T. N., Gentile, G., Abraham, W. R., Lünsdorf, H., et al. (2001). Alcalilimnicola halodurans gen. nov., sp. nov., an alkaliphilic, moderately halophilic and extremely halotolerant bacterium, isolated from sediments of soda-depositing Lake Natron, East Africa Rift Valley. Int. J. Syst. Evol. Microbiol. 51, 2133-2143. doi: 10.1099/00207713-516-2133

Yañez, J., Fierro, V., Mansilla, H. D., Figueroa, L., Cornejo, L., and Barnes, R. M. (2005). Arsenic speciation in human hair: a new perspective for epidemiological assessment in chronic arsenisism. J. Environ. Monit. 7, 1335-1341. doi: 10.1039/ B506313B

Yang, Y., Itahashi, S., Yokobori, S., and Yamagishi, A. (2008). UV-resistant bacteria isolated from upper troposphere and lower stratosphere. Biol. Sci. Space 22, 18-25. doi: $10.2187 /$ bss. 22.18

Zabel, H. P., König, H., and Winter, J. (1984). Isolation and characterization of a new coccoid methanogen, Methanogenium tatii spec. nov. from a solfataric field on Mount Tatio. Arch. Microbiol. 137, 308-315. doi: 10.1007/BF004 10727

Zellner, G., Boone, D. R., Keswani, J., Whitman, W. B., Woese, C. R., Hagelstein, A., et al. (1999). Reclassification of Methanogenium tationis and Methanogenium liminatans as Methanofollis tationis gen. nov., comb. nov. and Methanofollis liminatans comb. nov. and description of a new strain of Methanofollis liminatans. Int. J. Syst. Bacteriol. 49, 247-255. doi: 10.1099/00207713-49$1-247$

Zhang, S., Yan, L., Xing, W., Chen, P., Zhang, Y., and Wang, W. (2018). Acidithiobacillus ferroxidans and its potential application. Extremophiles 22, 563-579. doi: 10.1007/s00792-018-1024-9

Zhou, J. F., Gao, P. K., Dai, X. H., Cui, X. Y., Tian, H. M., Xie, J. J., et al. (2018). Heavy hydrocarbon degradation of crude oil by a novel thermophilic 
Geobacillus stearothermophilus strain A-2. Int. Biodeterior. Biodegradation 126, 224-230. doi: 10.1016/j.ibiod.2016.09.031

Zhou, W., Guo, W., Zhou, H., and Chen, X. (2016). Phenol degradation by Sulfobacillus acidophilus TPY via the meta-pathway. Microbiol. Res. 190, 37-45. doi: $10.1016 /$ j.micres.2016.05.005

Zhu, J. K. (2001). Plant salt tolerance. Trends Plant Sci. 6, 66-71. doi: 10.1016/ S1360-1385(00)01838-0

Zúñiga, L. R., Campos, V., Pinochet, H., and Prado, B. (1991). A limnological reconnaissance of Lake Tebenquiche, Salar de Atacama, Chile. Hydrobiologia 210, 19-24. doi: 10.1007/BF0001 4320
Conflict of Interest Statement: The authors declare that the research was conducted in the absence of any commercial or financial relationships that could be construed as a potential conflict of interest.

Copyright (อ 2018 Orellana, Macaya, Bravo, Dorochesi, Cumsille, Valencia, Rojas and Seeger. This is an open-access article distributed under the terms of the Creative Commons Attribution License (CC BY). The use, distribution or reproduction in other forums is permitted, provided the original author(s) and the copyright owner(s) are credited and that the original publication in this journal is cited, in accordance with accepted academic practice. No use, distribution or reproduction is permitted which does not comply with these terms. 